Zabytkoznawstwo i Konserwatorstwo XIII, Torun 2011

\title{
Ramy do obrazów Cechy konstrukcji i dekoracji
}

$\mathrm{Z}$

lota rama dla przeciętnego odbiorcy sztuki jest synonimem ramy w ogóle, a zwłaszcza tej dawnej. Złoto kojarzy się także z bogactwem, przepychem, prestiżem. Ramy, podobnie jak meble, nie zawsze były złocone, choć znakomita większość zachowanych ram została wykonana tą metoda. Często obok złocenia na ramach występują ślady wykorzystania innych technik, zaczerpniętych z malarstwa, rzeźby czy sposobów dekoracji mebli oraz wnętrz.

Historyczne techniki ramiarskie są identyczne z technikami innych dziedzin rzemiosła i sztuki. Ogólnie techniki ramiarskie można podzielić na:

- techniki uzyskiwania dekoracji (snycerka - ornamenty rzeźbione, frezowanie - ornament falisty, listwy profilowe, pastiglia, aggetti, scagliola - stiuk ramiarski, masa ramiarska - mastyka, masy drzewne, papier mâché, repusowany mosiądz);

- techniki pozłacania (mordanty emulsyjne i olejne, złocenia na bolus połyskowe i matowe, złocenia proszkowe);

- techniki matowienia gruntów (grain d'dore, poitille, azure, siatki, piasek), powierzchni złota (puncowanie, granito, powłoki proteinowe, olejne, żywiczne i emulsyjne);

- techniki malarskie (farby olejne bezpośrednio na drewnie, farby olejne i temperowe na zaprawach, na foliach metali); 
- techniki imitatorskie: trompe-o'leil, faux-marbre, imitacje hebanu, farby temperowe i emulsyjne na złocie, złote sgraffito, farby transparentne na złocie: pictura translucida, floriren, a'quatre coleurs, goldlaki, vermillion, ormoulu;

- techniki dekoracji drewna innym drewnem lub materiałem (intarsja, fornirowanie drewnem, w tym płatki hebanowe lub ich imitacja barwioną skórą wieloryba, płytki szylkretu);

- techniki dekoracji drewna innymi materiałami (inkrustacja, szylkret, markieteria);

- techniki lakierowania i woskowania drewna (imitacje laki, imitacje drewna - politury).

Typ ramy, to znaczy jej styl, a w nim rodzaj dekoracji, był uzależniony od kilku czynników:

- celu oprawiania (pojedynczy - obrazy dewocyjne w średniowieczu, ramy autorskie w XIX i XX wieku, należące do zbioru, np. ołtarz, wnętrze, galeria);

- miejsca przeznaczenia (kościół, wnętrze pałacowe, galeria);

- właściciela (Kościół katolicki - bogactwo dekoracji, wyznawcy religii protestanckiej - skromna dekoracja, dwór królewski, magnacki - cechy rodowe w dekoracji, właściciel świecki - standaryzacja dekoracji, czynnik ekonomiczny);

- rodzaju malarskiego przedstawienia (pejzaż, portret, scena mitologiczna, scena historyczna, martwa natura, abstrakcja).

Środkami wyrazu przynależności do powyższych grup były:

- kształt i wielkość ramy, w tym szerokość listwy i rodzaj profilu;

- rodzaj ornamentu, który mógł być rzeźbiony, odciskany, wysoki, płytki, podporządkowany konstrukcji lub zrywający z nia, dekoracja geometryczna, formy naturalne, przedstawienia mitologiczne, symboliczne, inskrypcje itd.;

- rodzaj opracowania powierzchni, czyli kolor i połysk, w tym farba i złocenia.

Do technik ramiarskich należą techniki pozłotnicze, przez wiele wieków te same dla różnych dziedzin sztuki, a także przedmiotów użytku codziennego mieszkańców wielu regionów kulturowych świata. 


\section{Cechy konstrukcji ram złoconych}

Cechy konstrukcji ram do obrazów wpisują się w ewolucję technologiczną mebli. Zarówno materiał, jak i techniki pozyskiwania, typy połączeń są $\mathrm{w}$ wielu przypadkach analogiczne albo zbliżone do mebli.

Konstrukcja ram jest bardzo ważna ze względu na pełnioną przez nie funkcję nośną dla obrazu. W miarę rozwoju stosowano do wyrobu ram coraz doskonalsze narzędzia, co miało przełożenie na typy złączy ${ }^{1}$.

Ogólna zasada budowy ram jest prawie niezmienna i niezwykle stabilna. Od czasu wprowadzenia płótna jako podobrazia w malarstwie sztalugowym w XVI wieku rama usamodzielniła się konstrukcyjnie. Jej funkcja nośna dla malowidła była tak samo ważna jak funkcja dekoracyjna. W średniowieczu oraz w XVI wieku podporządkowanie dekoracji konstrukcji jest wyraźne.

1 W Polsce już na przełomie XI i XII w. używane narzędzia były mało zróżnicowane. Siekierka służyła do obalania drewna, okorowywania i przecinania pni, okrzesywania gałęzi i do nadawania okraglakom pożądanego profilu. Płaskie powierzchnie wygładzano toporem, a z biegiem czasu strugiem lub ośnikiem. Używano także ostrych noży do ornamentów i małych figurek. Dość wcześnie pojawiła się cieślica z ostrzem ustawionym poprzecznie do osi toporzyska, służąca do wygładzania powierzchni oraz do wyżłabiania niecek i rowków. Także wcześnie zaczęto wykorzystywać dłuta, będące głównym narzędziem snycerskim. Piła upowszechniła się w naszym kraju dopiero w XIV w. - do tego czasu wyrabiano płazy i deski przez rozszczepianie (darcie); zob. I. Tłoczek, Polskie snycerstwo, Wrocław 1984. Do końca XVIII w. do cięcia drewna używano ręcznych pił, co uwidacznia się na drewnie w formie pasów. Po tej dacie stosowano piłę tarczową, która pozostawiała na powierzchni drewna ślady okręgów. Rozwój metalurgii ułatwił udoskonalenie narzędzi i ich wzbogacenie. Rodzaje dłut i ich liczbę określa technika obróbki drewna. Zwykle są to: wcinak - dłuto z prostym, płaskim ostrzem służące do wcinania się w drewno i do wygładzania płaszczyzn, skośnik - wcinak ze skośnym ostrzem, przydatny do nacinania brzegów, żłóbnik - dłuto z płaskim półokragłym ostrzem na łukowato zakrzywionym trzpieniu, kątnik płaski z ostrokątnym ostrzem do wycinania bruzd, felców, piesznia do wyrabiania gzymsów i drążeń. (Jest to podstawowy zestaw, zwykle jest ich więcej. W inwentarzu z 1573 r. sporządzonym przez Jerzego Szwarca, stolarza i snycerza króla Zygmunta Augusta, jest wymienionych 67 dłut snycerskich, 120 stolarskich i 260 strugów; zob. ibidem, s. 25). 
Większość ram jest zbudowana z czterech drewnianych części (graniaki, listwy) połączonych złączami, które mogły być dodatkowo wzmocnione kołkami, gwoździami, śrubami czy klejem. Gwoździe pojawiające się często na ramach stanowiły początkowo wyrób luksusowy ${ }^{2}$, wytwarzany przez kowali ręcznie, dlatego często spotykamy kołki jako wzmocnienie połączeń stolarskich. Sworznie kutych gwoździ mają przekrój trójkątny, prostokątny bądź kwadratowy, a głowę o nieregularnym kształcie. Około 1790 roku zaczęto maszynowo wyrabiać gwoździe o równych sworzniach i łbach. Rodzaj złącza zależał od rodzaju ramy (płaskie, z ornamentem ciagłym, rzeźbione ażurowe itd.), epoki (w różnych okresach niektóre typy były przedkładane nad inne), warsztatu i jego możliwości technologicznych.

Ramy występują w wielu kształtach i typach konstrukcyjnych; najczęściej są one prostokątne, kwadratowe, owalne, okragłe i wieloboczne. Ramiaki/listwy sa przeważnie połączone na stałe ze względu na przeznaczenie (rama do obrazu lub lustra) i chęć uzyskania odpowiedniego efektu plastycznego. Istnieją ramy płaskie lub wgłębne, bogato profilowane, wąskie lub szerokie, malowane, złocone, srebrzone, inkrustowane, obciagane różnymi materiałami, drewniane, marmurowe, szklane, metalowe, z mas plastycznych, z papier mâché.

Ramy są zazwyczaj podzielone na część dekoracyjną i konstrukcyjną̧3. Dokładnie dopasowane ze sobą narożniki listew drewnianych tworzą część

2 Gwoździe pojawiły się na drewnianych elementach już w XIII w.; zob. Tablice historyczne, oprac. W. Mizerski, Warszawa 1996, s. 298. Wyrabiano je najpierw przez kucie każdego osobno, potem w XIX w. prostokątne druty cięto i formowano na gwoździe, także ręcznie (choć metodę wyciagania drutu przez otworki opracowano już w XI w.; zob. ibidem, s. 299). Gwoździe kowalskie wykonywano z żelaza, a główki dekoracyjne z miedzi i mosiądzu; zob. I. Grzeluk, Stownik terminologiczny mebli, Biblioteka Muzealnictwa i Ochrony Zabytków, Ośrodek Dokumentacji Zabytków, Warszawa 1998, s. 213-214. Pierwsze maszynowe gwoździe były cienkie, po 1830 r. stały się grubsze. Maszynowe i cięte gwoździe pojawiły się po 1880 r.; zob. N. A. Smith, Old Furniture, Understanding the Craftsmen's Art. A guide to Collection, Appreciation and Preservation, New York 1991, s. 62-66. Ręcznie piłowane śruby pojawiły się ok. 1700 r. i były rzadsze niż ręczne gwoździe; zob. I. Swaczyna, Wybrane cechy konstrukcji jako kryterium identyfikacji mebli zabytkowych, Warszawa 1992, s. 29.

3 Konstrukcyjna, czyli tył, wyjaśniający budowę, oraz przód, określający rodzaj dekoracji, jaki został „nałożony” na konstrukcję. Jest kilka wariantów określających 
konstrukcyjna, na którą nakładano dekoracje charakterystyczne dla stylu danej epoki - część dekoracyjną. Poszczególne elementy ramy wykonywano osobno i potem łączono. Różne były nie tylko połączenia tych części, ale nierzadko także gatunek drewna. W jednej ramie można spotkać połączenie uciosowe, nakładkowe lub czopowe części konstrukcyjnej oraz połączenie na styk nakładanych na nie ornamentów. Każdy z tych elementów może stanowić osobny kawałek drewna lub też mogą one być do siebie przyklejone, tworząc laminowana „listwę”. Zwłaszcza owalne i okrągłe ramy miały taką budowę. Dekoracyjne, rzeźbione elementy, odciskane ornamenty lub złocenia są montowane i wykonywane później. Jak wspomniano, każda epoka, a nawet każdy kraj preferował inne surowce, czyli gatunki drewna. W Anglii, Holandii i Niemczech przeważało drewno iglaste, w Holandii często stosowano też dąb. We Włoszech obok gatunków iglastych stosowano także topolę, rzadziej lipę. Nierzadko wykorzystywano również gruszę i inne owocowe gatunki drewna do wyrobu ram w Holandii, Niemczech czy Polsce. Łączono też gatunki iglaste i liściaste na jednej ramie, często drewno gorszego gatunku, np. sosnowe, wykorzystując tylko w części konstrukcji. Lepsze gatunki drewna bądź dające się lepiej rzeźbić, polerować i wybarwiać ${ }^{4}$ stosowano do wykonywania elementów dekoracyjnych, nakładanych na konstrukcję. W XIX wieku do konstrukcji używano głównie taniego drewna sosnowego, a listwę dekoracyjna, również sosnową bądź lipową, ozdabiano ornamentem odciskanym w masie, co miało stanowić imitację snycerskiego opracowania ornamentów ${ }^{5}$.

tył i przód (ewentualnie front) ramy: konserwatorzy malarstwa operują określeniami związanymi z obrazem, czyli „lico” i „odwrocie”, ramiarze, mówiąc o tylnej części ramy, używają słowa „plecy”. Można także stosować określenia „awers” i „rewers”, których używa się w przypadku zabytkowej stolarki, czyli „strona tylnia - rewers, strona przednia - awers"; zob. J. Tajchman, Drewniane drzwi zabytkowe na terenie Polski, „Ochrona Zabytków”, 1991, nr 4, s. 269. Ponieważ w odniesieniu do ram stosuje się też określenie „bok”, najbardziej konsekwentne byłoby określenia „przód”, „tył” i „bok” ramy przy dokonywaniu opisów ikonograficznych, technologicznych i konserwatorskich.

4 Do wyrobu ram wykorzystywano również gatunki egzotyczne, takie jak heban, palisander czy mahoń.

5 Brakuje systematycznych badań nad drewnem stosowanym do wyrobu ram wynika to z przeprowadzonych przez autorkę badań w grupie reprezentatywnej ram 
Zapewne pierwotnym połączeniem czterech patyczków tworzących ramę było połączenie na krzyż $\dot{z}^{6}$, przewiązane rzemieniem. Najpopularniejszym i najprostszym połączeniem stolarskim używanym w przypadku ram jest połączenie na ucios (rys. 3). Jest ono jednak najsłabsze pod względem konstrukcyjnym, dlatego wymaga kołków, gwoździ lub kleju?

W całej ewolucji ramy i jej konstrukcji połączenie na ucios pojawiało się zwłaszcza w partii dekoracyjnej ramy, stanowiąc najprostsze połączenie listew ornamentalnych. Złącze uciosowe było też często wzmacniane kołkami. Najbardziej uniwersalne okazało się złącze uciosowe zakładkowe (rys. 4). Występuje ono zarówno na ramach średniowiecznych, renesansowych, barokowych, jak i XIX-wiecznych. Jego zalety to dobra stabilna konstrukcja oraz estetyczne połączenie listew ornamentalnych. W ramach średniowiecznych nierzadko stosowano złącza czopowe i czopowo-uciosowe (rys. 13-15), spotykane częściej w ramach włoskich w wariancie osadzonym i przelotowym bądź barokowych z listwami ażurowymi. Wczesnym i dość popularnym połączeniem jest złącze zakładkowe proste (rys. 8), często wzmocnione kołkami (rys. 9). Występuje ono zazwyczaj na ramach poliptyków gotyckich, ramach renesansowych, na których, tak jak w gotyckich, profile płyty sa płaskie z szerokim pasmem płaskiego fryzu pośrodku. W XVI wieku, obok kontynuacji złącz zakładkowych i ich wariantów, częste były, zwłaszcza w ramach włoskich, złącza na pióro. Połączenie takie spotykamy także na ramach niderlandzkich i belgijskich z XVII stulecia ${ }^{8}$. Szkielet konstrukcyjny tworzą graniaki o złączach czopowych, a listwy ażurowe są złączone na ucios.

W XVIII i XIX wieku powszechnie występowały złącza na ucios z obcym piórem. Ramy XIX-wieczne, z racji swego dużego ciężaru (odlewy gipsowe i odciski z masy ramiarskiej) i często dużego rozmiaru, wykształciły odrębną konstrukcję. Opierała się ona na wielu elementach drewnianych

wykonanych w różnych technikach pozłotnicznych oraz w technikach im towarzyszących.

6 Echo takich ram możemy odnaleźć na ramach gotyckich poliptyków.

7 Początkowo meble, w tym także ramy, były łączone na złącza i ewentualnie kołki, potem gwoździe, śruby. Złącza wzmacniane klejem są późniejsze.

P. Mitchell, L. Roberts, A bistory of European Picture Frames, London 1996, s. 20 . 
w częściach konstrukcyjnych - tzw. laminatach, nierzadko wykonanych nie z całej deski, ale z jej fragmentów w celu zmniejszenia ciężaru konstrukcji. Skomplikowane profile wymagały również nakładania szeregu mniejszych listew jedna na druga.

Złącze uciosowe występuje zazwyczaj na ramach XIX- i XX-wiecznych, jest wzmocnione kołkami (rys. 3), gwoździami, śrubami bądź trójkątami (rys. 10). Czasem trójkąty są dodawane na stare złącza w celu wzmocnienia ich stabilności. Te pojawiają się szczególnie często w XIX-wiecznych ramach, których produkcję determinował pośpiech i niska cena.

Odrębną i prawie niezmienną budowę mają ramy owalne i okragłe, połączone na złącza zakładkowe uciosowe.

Obok gatunku drewna, rodzaju ornamentu, sposobu dekoracji i typu zastosowanych złącz, równie ważny w przypadku ram jest rodzaj profilu. Każda epoka miała charakterystyczny profil. System profili ramiarskich został zaczerpnięty z gzymsów architektury klasycznej i składał się z elementów łuków, wałków, profili wklęsłych i ich fragmentów podzielonych platka. Ramy o prostym profilu wykonywano z jednego kawałka drewna, natomiast skomplikowane profile sklejano z kilku kawałków drewna.

Profile ramy można podzielić na trzy grupy: wznoszące, opadające i symetryczne. Kierunek wznoszenia i opadania wyznacza wewnętrzna krawędź ramy. Ramy o profilu odwrotnym, czyli opadającym, przybliżały optycznie obraz, a ramy o profilu prawidłowym, czyli wznoszącym, oddalały obraz od widza w kierunku ściany, tworząc głębię.

Ramy średniowieczne, tak jak antyczne, to konstrukcje skrzynkowe, o profilach płaskich, symetrycznych. Szerokie śródpasmo (fryz) od zewnattrz i wewnątrz było opatrzone listwami profilowymi o nieskomplikowanym przekroju. Stosowano kombinację półwałków i wklęsek. Dekorację podporządkowywano konstrukcji. Boki ram w poliptykach gotyckich i kasetonowych włoskiego renesansu były proste, przeznaczone do ogladania z przodu.

W XVI i XVII wieku we Włoszech i Hiszpanii były modne profile odwrotne. W 1621 roku wynaleziono maszynę do uzyskiwania ornamentu falowego, który odtąd pojawiał się na meblach i ramach w XVII i XVIII wieku. 
W XVII stuleciu profil ramy stał się wyższy. Spowodowało to silniejszą głębię przestrzeni wokół obrazu'. Profile otrzymywano w tym czasie przez sklejanie kilku frezowanych listewek, co dawało większe urozmaicenie. Pod koniec wieku profil podniósł się, a jego zewnętrzna krawędź „wyciagnęła się” i zaczęła przypominać dziób ptaka ${ }^{10}$. Dekoracja zaczęła odchodzić od konstrukcji, by w rokoku zupełnie nad nią zapanować. Linia stała się falista, profil wyższy i bardziej płynny, a odchylenie na bok pozwoliło na uzyskanie głębszej skocji. Pojawił się także profil w kształcie litery S - sima. Bok ramy został poszerzony, wycięty łukiem wklęsłym. Otrzymał własny pas ornamentalny. Ramy można było oglądać również z boku, a widok z przodu nie wywoływał wrażenia nakładania się dekoracji. Profil zaczął przypominać krowi róg odchylony na zewnątrz ${ }^{11}$. W tym okresie, zwłaszcza we Włoszech i Hiszpanii, modne były profile odwrotne, które powodowały optyczne odsunięcie obrazu od ściany. W XVIII wieku, obok rozwiniętych profili, występowały także profile proste z jednego kawałka drewna o przekroju pół i ćwierć wałka.

Klasycyzm charakteryzował się suchym ornamentalnym porządkiem, proponowanym przez Wincelmana - proste ramy, perełki, wole oczka, kokardy, wszystko bardzo precyzyjne i dokładne. Ramy stały się lżejsze oraz cieńsze. Popularne były owale do portretów; niektóre o prostym profilu, inne z korona (Salon Paryski z 1779 roku). Wzrosło zainteresowanie symboliką - liście oliwne, dębowe, wąż. Profil został uproszczony. Pozostały tylko dwa pasy dekoracyjne przy krawędziach, a wewnętrzną część podniesiono wysoko, tworząc w ten sposób głęboką wklęskę (skocję), stanowiąca część koła. Bok ramy był przeznaczony do oglądania z przodu.

9. Wynalezienie produkcji wielkoformatowych tafli szkła w 1687 r. spowodowało pewne zmiany w konstrukcji ramy. Pojawiło się po tym czasie wiele ram z przeznaczeniem dla pasteli i grafik, które miały płytszy felc. Natomiast po 1730 r. rozpoczęto produkcję oprawionych, oszklonych rysunków, grafik, gwaszy; zob. P. Mitchell, L. Roberts, op. cit., s. 43-44.

10 Ibidem, s. 59.

11 J. Wójcik, Dziewiętnastowieczne ramy do malowideł, praca dyplomowa napisana pod kier. prof. dr. W. Ślesińskiego, ASP w Krakowie, Kraków 1987, s. 75 [mps]. 
Wysokość często równa się szerokości. Te same profile można odnaleźć na obramieniach drzwi, okien, na ramach do luster i grafik ${ }^{12}$.

Empire wprowadził bardziej urozmaicony profil ram. Z tego czasu również zachowało się dużo owalnych ram, głównie do portretów. XIX-wieczny historyzm i eklektyzm powielały wzory dawne, choć niedosłownie.

Wiek XX powrócił do dawnych gotyckich płaskich profili (secesja), renesansowych ram skrzynkowych, a także barokowych.

Nowoczesne profile to uproszczenie formy, połączenie często żłobkowanych wałków i wklęsek w płynną linię profilu, podkreślającą jedynie skrajne linie dekoracją schematycznie tylko nawiązującą do wytwarzanych przez wieki wzorów.

Sposób zawieszania ram na ścianach wiąże się z ewolucją organizacji przestrzeni wnętrza. Jak pokazuja pompejańskie malowidła ścienne, w starożytnym Rzymie obrazy nie zawsze były wieszane na ścianach, ale na specjalnych stojakach. Praktykę zawieszania tkanin na ścianach obserwujemy na reliefach hellenistycznych ${ }^{13}$. Przetrwała ona do czasów średniowiecza, co można prześledzić chociażby na podstawie zachowanych obrazów i malowideł ściennych. Początkowo tkaniny wieszano tylko w otoczeniu łóżek, potem także w innych miejscach na ścianach ${ }^{14}$. Tapiserie służyły też jako obicia mebli. Pokrewne tym dwóm technikom było dekorowanie ścian drukowanym papierem - zwyczaj utrwalony pod wpływem malowideł chińskich i japońskich, obecny w Europie już w XVI wieku, a przeżywający swój złoty okres w XVIII stuleciu. Tapiserie często występowały również w XIX- i XX-wiecznych wnętrzach. Projektowaniem wzorów na tapety, czy wcześniej na tapiserie, zajmowali się niejednokrotnie znani artyści ${ }^{15}$. Spotykana już w starożytnym Rzymie i gotyku, przypomniana w renesansie i klasycyzmie, drewniana boazeria

12 P. Mitchell, L. Roberts, op. cit., s. 45.

13 M. Praz, An Illustrated History of Interior Decoration, Milan 1964, il. 27, s. 69. Technika znana już w starożytnym Egipcie od czasów XVIII Dynastii; zob. Słownik terminologiczny sztuk pieknych, pod red. K. Kubalskiej-Sulkiewicz, M. Bielskiej-Łach, A. Manteuffel-Szaroty, wyd. 2, Warszawa 1997, s. 199.

14 M. Praz, op. cit., s. 76, il. 38.

15 Między innymi: Rafael, Rubens, Boucher. Tapeta: niem. Tapete - pokrycie, franc. tapisserie; zob. Stownik terminologiczny sztuk pieknych, s. 411. 
narzucała organizację powierzchni ściany ${ }^{16}$. Znana w XVI-wiecznej Europie bliskowschodnia technika dekoracji ścian, mebli w formie malowanych i złoconych kurdybanów, szczególnie popularnych w Niderlandach, nie pozostawiała wiele miejsca na zawieszanie ${ }^{17}$. Unifikowanie wystroju wnętrz w okresie baroku, czyli podporządkowanie wszystkich elementów dekoracji wnętrza jednemu stylowemu projektowi, usztywniło podziały ściany i miejsc dla obrazów. Obramiano je wtedy zwykle sztukateriami. Tło zawieszanych malowideł było zatem różne w zależności od epoki, mody, gustów domowników, podobnie jak dziś. Trudno w tej kwestii ustalić jakieś zasady, można tylko zakreślić tendencje.

Obrazy wieszano więc na tapiseriach, boazeriach, tapetach, ścianach malowanych wielobarwnie, ale stawiano je równie chętnie na kominkach czy stolikach. Występowały zawieszki zarówno niewidoczne dla patrzącego, jak i dekoracyjne, zaakcentowane formą i materiałem, wieszane na dekoracyjnych taśmach ${ }^{18}$.

Wraz z rozwojem kolekcji malarstwa stworzono wnętrza skupione na prezentacji obrazu, a nie jego otoczenia, charakteryzujące się białymi ścianami i pustymi przestrzeniami ${ }^{19}$.

Ramy mocowano w rozmaity sposób. Było to uzależnione od ciężaru i przeznaczenia (obraz, pastel, grafika), a także od daty powstania i kraju pochodzenia ram. Występowały zawieszki pojedyncze na środku górnej listwy, podwójne, również montowane na górnej listwie, oraz podwójne montowane na bocznych listwach w górnej ich części. Początkowo, w XVI wieku, kiedy obrazy stały się bardziej samodzielne, zawieszano je płasko na ścianie, stosując zawieszki drewniane, sznurkowe, żelazne lub też, chociaż rzadziej, wycinając otwory na bocznych ramiakach, dzięki czemu można było nasadzić ramę na haki umieszczone w ścianie. W XVII i XVIII wieku zawieszki wykonywano głównie z kutego żelaza ${ }^{20}$ uformowanego w trójkąt, kwadrat lub prostokąt zakończony kółkiem - ucho.

16 Z franc. boiserie, boiser - cembrować, obkładać drewnem; ibidem, s. 48.

17 Rozpowszechniona w średniowieczu w mieście Kordoba, ibidem, s. 203.

18 Czasem zawieszki były widoczne, dlatego też je złocono.

19 Obecna w muzealnictwie tendencja do dzielenia tej przestrzeni, kolorem i wewnętrznymi podziałami, wyraża brak konsensusu w sprawie stosunku: obraz, rama, otoczenie i widz.

20 W Niderlandach głównie dębowe. 
Zwykle, tak jak wcześniej, mocowano je na środku górnej listwy. Na początku XVIII wieku, kiedy obrazy rozmieszczano w większej odległości od siebie, zmienił się nieco sposób zawieszania ${ }^{21}$. Wpłynęło to na rodzaj i formę mocowania. Obrazy zazwyczaj wieszano na zawieszkach umocowanych na bocznych listwach, za pomocą sznurka - były one wówczas lekko odchylone od ściany.

Zawieszki lub ślady po nich na listwach nie tylko spełniaja swoja funkcję praktyczna, ale dostarczają nam także informacji o wieku ramy czy pierwotnym sposobie zawieszenia, czyli kompozycji obrazu (w pionie czy w poziomie). Oczywiście, im starsze ramy, tym więcej jest zawieszek lub dziur po gwoździach je mocujących. Późniejsze zawieszki bywały również mosiężne.

\section{Sposoby dekoracji}

Praktykę złocenia przedmiotów, a nawet ciał²2, należy tłumaczyć nie tylko względami użytkowymi i dekoracyjnymi, ale przede wszystkim symbolicznymi. Złoto (łac. aurum, hebr. aor) oznacza światło ${ }^{23}$. Było ono obecne w obrzędach religijnych (złocenie rogów byka w starożytnej Grecji, złote łańcuchy w świątyni Salomona, złote dachówki pałacu Krezusa), w sztuce

21 Nie tak ciasno jak wcześniej w gabinetach, jeden przy drugim, ale dalej w kilku rzędach. Z. Waźbiński, Założenia programowe śodkowoeuropejskich galerii malarstwa, „Acta Universitatis Nicolai Copernici. Zabytkoznawstwo i Konserwatorstwo”, Torun 1979, s. 171.

22 W tym nawet ciał ludzkich. Egipcjanie mieli zwyczaj złocić ważne miejsca ciała, takie jak usta i język, aby mogli jeść i mówić, także dłonie, serce, stawy, genitalia. Płatki złota kładziono bezpośrednio na zwłokach. P. Hatchfield, R. Newman, Ancient Egyptian Gilding Methods, [w:] A. Lins et al., Gilded Wood, Conservation and History, Madison 1991, s. 29.

23 „Złoto jest więc obrazem światła słonecznego, a także boskiej inteligencji. [...] Obrazem słońca w człowieku jest serce, tak jak złoto jest nim w ziemi. [...] Złoto symbolizuje wszystko, co wyższe, gloryfikację, czyli »stan czwarty« po czerni (wina, pokut), bieli (wybaczenie, niewinność), czerwieni (sublimacja, namiętność)", J. E. Cirlot, Stownik symboli, Kraków 2000, s. 447. 
(księgi, hieroglify, malowidła ścienne), w przedmiotach codziennego użytku (tkaniny, odzież) ${ }^{24}$.

Wśród zachowanych źródeł pisanych, traktatów, poradników, podręczników można prześledzić ciąg rozwoju technik ramiarskich oraz ewolucję materiałów ${ }^{25}$. Dziedzina ta bowiem rozwijała się równolegle z innymi

24 T. Sadziak, Klejowe i olejne prace pozłotnicze, Ośrodek Dokumentacji Zabytków, Warszawa 1981, s. 7-8.

25 Już w Rekopisie lukańskim (XVIII-XIX w.) spotykamy opis dwóch sposobów złocenia na połysk (pozłota z połyskiem), na białko oraz gumę migdałową i na mordant - olej z szafranem i gumą (J. Hopliński, Farby i spoiwa malarskie, Wrocław 1990, s. 93; E. Berger, Quellen und Technik der Fresco-, Ol-, und Tempera-Malerei des Mittelalters, München 1912, s. 13). Heraklisz również wymienia dwa sposoby złocenia - matowy i połyskowy. Pierwszy z zastosowaniem oleju, czyli kleju greckiego, drugi - złocenie na mokrym podkładzie złożonym z ugru, kleju i białka. Teofil do złocenia płatkami złota i srebra stosuje białko jaja bez dodatku wody, a płatki cyny przykleja woskiem. (J. Hopliński, op. cit., s. 95). Mnich Dionysios poleca złocić na zaprawie olejnej z gipsem, ugrem, ziemią hiszpańska, biela ołowianą i dodatkiem zmielonych małży. Złocenie połyskowe radzi przygotowywać z bolusu z klejem (Hermeneja tez Dzografikes, VI-XVI w. Trier, 1855, [w:] J. Hopliński, op. cit., s. 98; E. Berger, op. cit., s. 73). Źródła Mappae Clavicula (XII w.) i Rekopis bolonski (pol. XV w.) podają przepisy zapraw przygotowywane na oleju lnianym z wypełniaczami w postaci pigmentów, głównie ugru, zieleni hiszpańskiej (J. Hopliński, op. cit., s. 100-102; E. Berger, op. cit., s. 128). Manuskrypt Petrusa de S. Audemara wspomina o złoceniu sproszkowaną cyną na kleju oraz o złoceniu na polerowanej wytrawie z gumy arabskiej, amoniakalnej i gipsu (M. Merriefield, Original Treaties on the Arts of Painting, vol. 1, New York 1967, s. 146, 195, 156). W Rekopisie strasburskim znajdujemy przepisy na wytrawy, dzielące się na takie, które da się polerować, jak np. te z udziałem soku czosnkowego czy gum i gumożywic, czerwonego bolusu, minii, palonych kości, odwodnionego witriolu cynkowego lub wypełniaczy, oraz takie, których nie da się polerować kamieniem po wyschnięciu, związaniu spoiwa. Są to wytrawy oparte na zagęszczanych olejach i pokostach z dodatkiem wypełniaczy, takich jak bolusy, ugry/ochry, na palonych i mielonych kościach oraz na żywicach, takich jak bursztyn, kalafonia, sandarak (V. R. Borradaile, The Strasburg Manuscript, München 1976; J. Flik, K. Wantuch, Z łocenie „Farbami złotymi” wedtug Manuskryptu strasburskiego z ok. 1400 roku, ,Acta Universitatis Nicolai Copernici. Zabytkoznawstwo i Konserwatorstwo”, 1998, t. 30, s. 51-71). C. Cennini (XV w.) do zaprawy stosował gips albo kaolin z klejem skórnym, kostnym bądź czosnkowym, a złocił na ziemi zielonej (ta wzmacnia barwę złota) bądź na bolusie z białkiem. Złocił płatkiem i proszkiem metalu po zwilżeniu spirytusem. Znał też mordant (zagęszczone spoiwo) czosnkowy z wypełniaczami - biel ołowiana i bolus. Zalecał go stoso- 
gałęziami rzemiosła, m.in. produkcją mebli bądź ołtarzy, a także z rzeźba, malarstwem i architektura. Przenikały się one wzajemnie w procesie wspólnego rozwoju. Podobne były nie tylko ornamenty czy profile, ale też kolorystyka i materiały użyte do ich sporządzenia.

W starożytnym Egipcie stosowano płatki srebra, złota, cyny i proszki metali obok polichromii. Ponieważ nie zachowały się egipskie ramy, techniki pozłotnicze można wiązać jedynie z innymi złoconymi zabytkami kultury starożytnego Egiptu, takimi jak meble, sarkofagi czy maski pośmiertne. Płatki metali były kładzione na substancje organiczne, takie jak: skóra, drewno bez spoiwa, lub na brązową żywiczną wytrawę $e^{26}$. Złocono jednak również zaprawę. W okresie Starego Państwa wykorzystywano bolus. Pomiędzy warstwy zaprawy nakładano tkaninę lnianą.

Grecy kontynuowali techniki egipskie, o czym świadczą zachowane przekazy. Na przykład Homer w swojej Odysei opisuje sposób klepania złota $^{27}$.

wać na drewno, żelazo i miedź (C. Cennini, Trattato della pictura, 1437, [w:] E. Berger, op. cit., s. 102). Le Begue (XVI w.) polecał złocić ochra zmieszaną z białkiem jajka (M. Merriefield, op. cit., s. 238). Vasari (XVI w.) zaprawę wykonywał tak jak Cennini, z gipsu i kleju, a bolus rozprowadzał białkiem jaja i zwilżał do złocenia czystą woda. $\mathrm{Na}$ ścianę, kamień, metal, drewno i skórę polecał mordant (barwicę) na bazie oleju lnianego oraz drugi, tzw. szybki, ze spoiwa gumowego (J. Hopliński, op. cit., s. 110). Borghini (XVII w.) zaleca sporządzenie zaprawy z gipsu i makki w stosunku 1:1 oraz mieszaniny kleju i oleju; De Mayerne (XVII w.) - z kredy i kleju, jako pierwsza warstwa, oraz ciasto sporządzone z oleju, bieli ołowianej i umbry (J. Hopliński, op. cit., s. 112, 116). Manuskrypt brukselski (pierwsza poł. XVII w.) podaje przepis białkowy na zabezpieczanie ram przed kurzem i zanieczyszczeniami pochodzącymi od much oraz wymienia trzy rodzaje złotych gruntów stosowanych przez malarzy. O „Estofferie”, czyli jak złocić - rodzaje złocen, podaje trzy rodzaje „złotych gruntów”: aurum contusum - malowanie, pisanie „złotem”, polerowane; aurum politum - polerować, rozjaśniać i zacieniać, brązowić; aurum impolitum - głupie złoto, bez blasku, splendoru (M. Merriefield, op. cit., s. 816, 830). Manuskryptpadewski (XVII w.) podaje przepis na werniks do ram z kalafonii i spirytusu winnego.

${ }_{26}$ Z IV w. naszej ery pochodzi Papirus lejdejski opisujący techniki odlewania i imitowania metali. Źródło napisane po grecku przekazuje receptury z dwóch pierwszych wieków przed naszą era: Phisica et Mystica, Materia Medica. P. Hatchfield, R. Newman, op. cit., s. 28; T. Sadziak, op. cit., datuje go na III w. n.e., s. 8.

27 T. Sadziak, op. cit., s. 8. 
Rzymianie przejęli technikę złocenia od Greków, stosując do tego białko jajka i „leukoforon, czyli podkład podobny do bolusu. Rozpowszechnili także złocenie olejne, zwane klejem greckim"28.

Tradycji złocenia mebli, choć pojawiającej się w starożytnym Egip$\operatorname{cie}^{29}$, Grecji i Rzymie obok innych technik dekoracji powierzchni mebli, można doszukiwać się w znanym już w Mezopotamii i Bizancjum oraz kontynuowanym w okresie wczesnochrześcijańskim zwyczaju oprawiania małych dyptyków w metalowe ramy, mebli kościelnych złotą blachą, a także kolorowymi emaliami i kamieniami szlachetnymi ${ }^{30}$.

W czasach, kiedy ramy były związane z architekturą czy meblarstwem, techniki jej wykonywania rozwijały się równolegle do tych dziedzin, których ramy były niejako integralnymi elementami, tj. malarstwa i architektury w okresie starożytnym, romańskim i średniowiecznym. Ramy romańskie i gotyckie korespondowały z powierzchnią obrazu tak jak w ikonie. Płaszczyzna środkowa mieściła właściwy wizerunek, prawie zawsze była wycięta w powierzchni deski, ujęta po bokach w szerokie, płaskie margines $^{31}$. Ramy stanowiące integralną część obrazu nasadzano na płyty i dzięki temu tworzyły dobre wzmocnienie całego układu. Pod koniec średniowiecza wielkie poliptyki często miały już ramy nakładane na obraz bardziej jako dekorację niż element konstrukcyjny. Występowały także bardzo proste ramy płaskie $z$ płytko profilowanymi listwami zewnętrznymi i wewnętrznymi. Ramy gruntowano wraz z deskami stanowiącymi podłoże obrazu. Zwykle na ramach można zaobserwować zastosowanie kilku technik i osiaggnięcie dzięki temu wielu efektów plastycznych, m.in. przez zestawienie techniki połyskowej i matowej. Obie techniki złocenia i imitacji złota, czyli technika złocistych laserunków ${ }^{32}$ na srebrze, wywodzą

28 Ibidem, s. 9.

29 Technika pozyskiwania złotych płatków czy folii jest datowana na VI Dynastię -2300 r. p.n.e. P. Hatchfield, R. Newman, op. cit., s. 28.

30 G. Kaesz, Meble stylowe, Wrocław 1990, s. 64.

31 A. Stange, L. Cremer, Alte Bilderrahmen, Darmstadt 1958, s. 12.

32 Już w Papirusach tebańskich, starożytnym traktacie, odnajdujemy receptury na powlekanie folii laserunkami; zob. S. Stawicki, Papirusy tebańskie. Antyczne \{́ródto wiedsy o technikeach artystycznych, Warszawa 1987, \& 52, Pozłacanie srebra - sandarak zmieszany z cynobrem na srebro, \& 74, s. 321. 
się od złocenia metali. W średniowieczu używano płatków następujących metali: złota, cyny i srebra ${ }^{33}$. Ten ostatni stosowano jako substytut złota i pokrywano złocistymi lub innymi kolorowymi laserunkami. Wykorzystywano także srebro, ale głównie do imitacji zbroi. Jednak już C. Cennini ostrzegał, że srebro ciemnieje i że należy raczej używać płatków cyny ${ }^{34}$. Charakterystyczne dla gotyku są również ornamenty wytłaczane lub ryte w świeżej zaprawie za pomocą rylców, wybieraków oraz, już po pozłoceniu, za pomocą punc i chwiejaków.

Zanim na meblach (w tym na ramach) rozwinęła się technika złocenia płatkami na zaprawach klejowo-gipsowych i klejowo-kredowych, złocono bezpośrednio drewniane podłoże bądź blachy czy odlewy metalowe za pomocą wytraw, czyli podkładów pod złocenia. Ramy integralnie związane z obrazem, jak ikony, przez kowczeg, stanowily kolorystyczne bądź ikonograficzne dopełnienie obrazu w kolorze i doborze ornamentów. Często występowała dekoracja patronowa szerokiego śródpasma między profilami złoconymi.

Ramy poliptyków, zwłaszcza włoskich, były również często różnobarwnie lub jednokolorowo malowane w technice złotego sgraffito/sgraffito pozłotniczego. Polerowane złote płatki pokrywano farbą temperowa, a następnie miękkimi patyczkami wydrapywano wzór wcześniej delikatnie wyryty w zaprawie. Odwrotnością tej techniki jest malowanie złotą farbą delikatnych wzorów na farbie temperowej. Technika złotego sgraffito, podobnie jak technika imitacji tkanin złotolitych czy wzorów damasceńskich na togach, zasłonach, dywanach przedstawianych na średniowiecznych obrazach, wywodzi się od bardzo lubianego w tej epoce laserowania metali na różne odcienie. Początkowo były to wzory geometryczne, z czasem również motywy zaczerpnięte $z$ fauny i flory, moreski i arabeski ${ }^{35}$.

Pierwsze ramy mocno nawiązywały swą konstrukcją i dekoracją do architektury - niezależnie od tego, czy mówimy o środkowoeuropejskich

33 Wczesne użycie płatków cyny pokrytych złocistymi laserunkami odnajdujemy w kaplicy św. Stefana w Chaper House, Westminster w Anglii z 1353 r. Ch. Eastlake, Methods and materials of Painting of the Great Schools and Masters, vol. 1, New York 1960, s. 123-124.

34 Ch. Eastlake, op. cit., s. 124.

35 T. Sadziak, op. cit., s. 9. 
ołtarzach, czy włoskich tabernakulach. Sa to obramienia otworów okiennych i drzwiowych, fresków oraz bordiury manuskryptów. We Włoszech obok polichromii występuje dekoracja wypukła - pastiglia $a^{36}$ (rys. 4a), oraz złocenie bezpośrednio na drewnie orzecha (rys. 4b). Dekoracje te pojawiają się zarówno na ramach tabernakulowych, jak i na skrzyniowych typu cassetta - od nich się wywodzących. Podobną technikę można również odnaleźć na skrzyniach cassoni. Dekoracje były złocone, czasem także polichromowane ${ }^{37}$. Metodę zbliżoną do puncowania stanowiło granito ${ }^{38}$, dające możliwości tworzenia planów walorowych. Pierwszy plan był polerowany, a dalsze matowione techniką puncowania lub przez nałożenie powłoki. Stosowano metale szlachetne, kamienie szlachetne, dobre gatunki drewna, np. mahoń. Technika trompe-ołeil takie materiały właśnie imitowała malarsko i zaczęła pojawiać się na ramach zwłaszcza w krajach północnych w XVI wieku. W drugiej połowie tego stulecia upowszechnił się, ukształtowany we Włoszech, typ ramy listwowej, skromnie profilowanej, polerowanej i malowanej. W tym czasie na północy i w krajach saksońskich pojawiały się skromne ramy malowane ${ }^{39}$ lub bejcowane w kolorach czarnym i brązowym ${ }^{40}$. Polichromia była najczęściej olejna lub olejno-żywiczna, kładziona bezpośrednio na drewnie ${ }^{41}$.

36 „Szaty złotolite” to rodzaj ornamentu patronowego występującego szczególnie często na szatach postaci poliptyków z XV w. Dekoracje te miały spoiwo emulsyjne oparte na jajku lub jego częściach z dodatkiem olejów schnących. Były też dodatki żywiczne, spoiwa czysto żywiczne; J. Flik, M. Grzesik-Zawadzka, Ornament patronowy. Rekonstrukcja techniki na podstawie kwater ottarza św. Piotra i Pawla z. Legnicy, „Acta Universitatis Nicolai Copernici. Zabytkoznawstwo i Konserwatorstwo”, 1995, t. 26, s. $24-25$.

37 P. Mitchell, L. Roberts, op. cit., s. 21.

38 Głównie na ramach bolońskich z XVI w. typu cassetta; S. Starling, Italian Frames, [w:] The Art of the Edge: European Frames 1300-1900, New Haven 1986, s. 30.

39 Na gruncie lub bezpośrednio na drewnie.

40 T. Mielniczuk, B. Grzegorzewski, Historia ramy do obrazu, Warszawa 1977, s. 21.

41 Do 1685 r. w Niderlandach złocenia wykonywano głównie na wytrawach olejnych/emulsyjnych. Złocenia połyskowe pojawiają się po tej dacie, czyli po przybyciu hugenockich rzemieślników. 
W okresie manieryzmu ramy zestawiano z różnych gatunków drewna albo kamieni lub ich imitacji. W miarę rozwoju manieryzmu płatek złota stawał się jaśniejszy, chłodniejszy, cytrynowy.

Od lat 30. XVII wieku zaczęły upowszechniać się ramy szylkretowe wyłożone czerwienią, których naroża zdobiono metalicznymi okuciami ${ }^{42}$. W okresie baroku we Włoszech ramy były zawsze bardzo głębokie, pełnoplastyczne, złocone, rzadziej wykonywane w technice matowej i połyskowej. Ramy flamandzkie w XVII wieku miały bardzo zróżnicowany wyglą $^{43}$ : bogato profilowane, listwowe, $\mathrm{z}$ dekoracjami rzeźbiarskimi, malowane na jednolity często kolor i pokryte ażurową plecionką, złocone i polerowane, fornirowane hebanem ${ }^{44}$, bejcowane na brąz i czerń, czasem wzbogacone o ornament falisty ${ }^{45}$ lub ,żyłki”, czyli złocone cienkie płaskie lub skośne profile przy świetle ramy, tj. przy wewnętrznej krawędzi, dębowe o naturalnych kolorach, lekko woskowane.

W XVII wieku w Niemczech i Austrii do wyrobu ram powszechnie stosowano drewno gruszy. W krajach alpejskich konstrukcję i ornamenty wykonywano z jednego kawałka drewna $\mathrm{i}$ złocono na mat, a brzegi na połysk ${ }^{46}$.

Charakterystyczne dla Hiszpanii i Portugalii są ramy o profilu odwrotnym, czyli opadającym, a nie wznoszącym. W Hiszpanii częściej występowały folie srebrne niż złote. Na sosnową konstrukcję nakładano bardziej szlachetne gatunki drewna, tj. mahoń, heban, lipę, gruszę, orzech. Ornament był gruby i mięsisty. W całej Europie, a zwłaszcza we Francji i Niderlandach, w połowie XVII wieku pojawiły się skomplikowane ramy z bordiura ze szkła, tzw. lustra, w postaci wyciętej w gruncie części narożnej lub środkowej, dzielącej w ten sposób listwę na różne obszary pla-

42 A. Stange, L. Kremer, Alte Bilderrahmen, Darmstadt 1958, s. 18.

43 T. Mielniczuk, B. Grzegorzewski, op. cit., s. 25-30.

44 Już w XVII w. podrabiano heban barwioną skórą wieloryba. Można ją rozpoznać na ramie po zmianie koloru - „wypłowieniu”. Najpierw fornir hebanowy cięto pod kątem, potem prosto. Informacje - M. Bijl, kierownik Pracowni Konserwatorskiej w Rijksmuseum, Amsterdam 1997.

45 Powstały w niemieckim warsztacie snycerskim Hansa Schwarhardta ok. 1600 r. T. Mielniczuk, B. Grzegorzewski, op. cit., s. 30.

46 C. Grimm, Alte Bilderrabmen, München 1986, s. 24. 
styczne. Jedynie ramy francuskie pod koniec XVII stulecia miały niekiedy złocone dekoracje z gipsu. Ornamenty były delikatne, płytko rzeźbione. Występowały też ramy francuskie, płynniej profilowane i złocone w obu technikach - matowej i połyskowej. Charakterystyczne dla ram francuskich, szczególnie barokowych, jest matowienie wybranych płaskich części ramy za pomocą piasku naniesionego z klejem na zagruntowaną wcześniej powierzchnię $-z$ franc. „sandelin”. Piasek ten potem złocono w technice matowej, znanej i stosowanej już przed połowa XVIII wieku ${ }^{47}$. We Francji w epokach ludwikańskich, począwszy od Ludwika XIV, wykształcił się rodzaj przemysłu ramiarskiego, w którym poszczególne prace przy ramie dzielono między wielu specjalistów. W XVIII wieku ramy składano z wcześniej wyrzeźbionych w drewnie, dłuższych kawałków ornamentów, a następnie zaprawiano. System ten został udoskonalony w epoce Ludwika XV, w czasach dużego popytu na wszystkie przedmioty artystyczne będące częścią wyposażenia wielu bogatych królewskich i magnackich wnętrz ${ }^{48}$.

Zatrudniani do prac pozłotniczych rzemieślnicy cudzoziemscy, zwłaszcza wyznania innego niz katolickie, zmuszeni do opuszczenia Francji po wydaniu edyktu nantejskiego w 1685 roku, przenieśli przywiezione tam wcześniej przez Włochów i Hiszpanów techniki i wzornictwo francuskie do innych krajów europejskich ${ }^{49}$. Okres ten stanowił złoty wiek wyrobu ram, sprzedawanych po zawrotnych cenach, porównywalnych z cenami obrazów. Osiagnięto wówczas najwyższy poziom kunsztu snycerskiego i pozłotniczego.

Rokoko wprowadziło we wzornictwie nowy profil w formie S, a także nowe ornamenty (rocaille, kogucie grzebienie, płomienie). Zmienił się kolor bolusu na czerwień wenecką, a złota - na jaśniejszy i cieplejszy.

47 U. Sierszyńska, Uzupełnianie ubytków pozłoty w ramach złoconych, praca magisterska napisana pod kier. doc. dr Marii Roznerskiej, ZKMiRzP, Toruń 1993, s. 8 [mps].

48 B. B. Considine, The gilders Art in Eighteenth-Century France, [w:] A. Lins et al., op. cit., s. 87-90.

49 Nie bez oporu lokalnych tradycji. Na przykład w Holandii ramy w stylu Ludwik XIII i XIV, we Francji polerowane, w Holandii matowe. H. Heydenryk Jr., The Art and History of Frames, New York 1964, s. 71. 
Występowało znacznie mniej elementów polerowanych niż wcześniej. Ornament stał się wyższy, głęboko rzeźbiony oraz ażurowy.

W epoce klasycyzmu, wraz ze zmianą ornamentyki na grecką i egipską, odcień złota stał się jaśniejszy, a relief dekoracji - płytszy i bardziej graficzny. Dominował duży kontrast pomiędzy strefami matowymi a połyskowymi. Płatki kładziono z niezwykła precyzja - małe zakładki i mało poprawek $^{50}$. Skocja była najczęściej matowa - mat uzyskiwano przez nałożenie słabej powłoki klejowej. Popularne stały się także, zwłaszcza przy dużych ramach, ornamenty narożnikowe, wykonane z repusowanej miedzi lub mosiądzu i złocone (np. tzw. ramy schinkielowskie). Ornamenty rzeźbiono bardzo płasko. Znane są też kolorowo tonowane złocenia a'quatre coleurs ${ }^{51}$.

Obok elementów drewnianych na ramach pojawiały się aplikacje ze złoconego metalu. Od pierwszej połowy XVIII wieku produkowano także ramy ze złoconego papier mâchế $e^{52}$.

Ramy z okresu biedermeier miały prosta, skromną formę, często były srebrzone i delikatnie laserowane w złotym bądź transparentnym kolorze.

Rozwój stylu w XIX wieku pokazuje wszystko to, co stanowiło w różnych epokach kwintesencję terminu „forma klasyczna” lub „forma artystyczna": najpierw dekoracja antykizująca, później powrót do form gotyckich, a następnie późnobarokowych, ,zdegradowanych” do płaskiego rysunku ornamentowego. Odpowiednią ornamentykę można było, ze względu na metody jej tworzenia, powtarzać, dysponować nią, ponieważ wykorzystywano ja zazwyczaj w nałożonej masie modelunkowej za pomocą form negatywowych. Popularny w Europie stał się styl oparty na zasadzie horror vacui. Style historyczne były w pełni wykorzystywane w przemyśle ramiarskim, wzorniki powielały niezliczone „nowe” ornamenty, które tworzyły swoistą kompilację, mieszankę wielu motywów dekoracyjnych ${ }^{53}$, często dobieranych do konkretnego motywu w obrazie. Większość

50 B. B. Considine, op. cit., s. 90-93.

51 U. Sierszyńska, op. cit., s. 9.

52 Masa wykonana z papki papierowej, gipsu i kleju, używana do wyrobu elementów dekoracyjnych okolicznościowych, zabawek, kubków itp. Stownik terminologiczny sztuk pieknych, s. 301.

53 P. Mitchell, L. Roberts, op. cit., s. 49. 
ramiarzy w XIX wieku nie uważała, że obraz potrzebuje indywidualnie dobranej ramy ${ }^{54}$. Wytwórstwo ram zostało sprowadzone do prawie czysto mechanicznej procedury. Większość motywów stanowiła niedbałe kopie ram Ludwika XIII, z przesadzona głębokością roślinnego motywu. Imitacje XVII-wiecznych rzeźbionych liści odlewano w gipsie - wyglądały dzięki temu jak wykonane z żelaza. Ramy prawie zawsze były wysoko złocone, bez żadnej patyny, tonowania połysku; były też przeważnie bardzo szerokie i głębokie, a wzory toporne.

$\mathrm{Na}$ Salonie w latach 1852-1871 preferowano ramy historyczne, zwłaszcza do ,akademików”, ze względu na aspekt ekonomiczny i praktyczny, np. najchętniej neoklasycystyczne, które pasowały przede wszystkim do pejzaży. W późniejszych latach XIX wieku pojawiły się ramy typu „barbizon” związane z obrazami tej formacji. Charakteryzowały się one różnorodnością motywów ciagłych w miejscu dotąd dekorowanym dość oszczędnie - skocji. Motyw ten reprodukowano we wszystkich rozmiarach. Ten dekoracyjny, schodkowy profil pasował szczególnie do pejzaży, tworząc głębię - wrażenie przestrzeni. Mniej do obrazów z tej epoki pasował popularny typ reprodukcji barokowej ramy w „stylu Ludwika XIV”, bardzo popularny zwłaszcza w kręgach (mającej mniejsze aspiracje) klasy średniej. Pozostał on modny do początku XX wieku. Podobnym powodzeniem cieszyły się reprodukcje ram regencyjnych i ram w „stylu Ludwika XV", szczególnie do oprawy tzw. starych mistrzów ${ }^{55}$.

Oprócz przybierania przez ramy historyczne form w sumie płaskich, inną ich cechą charakterystyczną były często występujące, jasne, płaskie pasma (dosł. „śródpasma”) między brzegiem obrazu i wewnętrzną krawędziaj; ramy te nie zaczynały się nagle profilem, jak w przypadku ram klasycznych ${ }^{56}$.

Nowe ruchy artystyczne, przeciwne skostniałym zasadom sztuki akademickiej, wniosły również nowe spojrzenie na stosunek ramy do obrazu. Inne postrzeganie oprawy dzieł nowoczesnych artystów odrzucało wszystko, co dotyczyło przeszłości. Proste w strukturze rodzaje ornamentów zapoczątkował Salon w 1865 roku, kiedy Whistler pokazał La Princesse.

\footnotetext{
54 H. Heydenryk Jr., op. cit., s. 77.

55 P. Mitchell, L. Roberts, op. cit., s. 49.

56 C. Grimm, op. cit., s. 26.
} 
Wtedy też impresjoniści zaczęli oprawiać swoje obrazy, jednakże takie przypadki należały do rzadkości. Odrzucili oni bowiem złocone ramy, przeszkadzające w odbiorze nowej sztuki, np. bardzo ,gryzły się" z tonami pomarańczu i żółcieni na płótnach. Wykorzystywali także uszkodzone przeciętne ramy barokowe ze źle zachowanymi złoceniami i malowali je niezbyt starannie jasną farbą. Używali białych ram, które tonowali lekko żółcieniami chromowymi i vermillionem ${ }^{57}$. Do takiego koloru pasował każdy inny ton. Uważali, że złoto zbytnio rozprasza uwagę i odciaga widza od obrazu - gra światła ${ }^{58}$. Mimo to oprawiali niekiedy swe dzieła ramami złoconymi, co dokumentuja zdjęcia i obrazy w obrazach. Każdy z nich indywidualnie podchodził do ram, często robiąc szkice. Vincent van Gogh czasem używał bardziej kolorowych ram, Georges Seurat malował na ramach kropki - postanowił zniwelować do minimum granicę między obrazem i rama, pokrywając ramę kropkami w tej samej kolorystyce co otoczenie w obrazie, a Edgar Degas projektował wariacje ram złoconych, wprowadził cienkie śródpasmo, kawałek maty, pomiędzy obraz a ramę, rodzaj passe-partout, które malowat.

Angielscy prerafaelici sami tworzyli nowe kombinacje tradycyjnej ornamentyki na swoich ramach, celowo zaprojektowanych jako płaskie listwy. Wykorzystywali także stare techniki, takie jak pastiglia czy złote sgraffito. Poszukiwania form pierwotnych spowodowały włączenie również wzorów pozaeuropejskich. W latach 60. i 70. XIX wieku pojawiły się motywy egipskie i arabskie na bazie profilu neoklasycznego. Wtedy też zaczęły przenikać motywy japońskie (asymetria, stylizowane ornamenty organiczne). Odzwierciedlało to zainteresowanie artystów Bliskim i Dalekim Wschodem.

Ruch Nazareńczyków wpłynął w pewien sposób na podejście samych artystów do kwestii oprawy obrazów, wielu z nich samodzielnie projektowało ramy do swoich dzieł. W swej stylistyce były one zbliżone do gotyckich i renesansowych ołtarzy.

57 Żółtawoczerwony lakier dający połysk pozłocie, 2 uncje annotto, 1 uncja gamboges, 1 uncja vermillionu, $1 / 2$ uncji smoczej krwi, 2 uncje soli tartaru, 18 ziaren szafranu, gotować w litrze wody do zredukowania płynu o 1/4. Następnie przeciera się gęsty płyn przez muślin lub jedwab. The glider's Manual, New York, Excelsior Publishing House, Mckeon \& Schofield, reprint, Society of Gilders, Waszyngton 1990, s. 23.

58 P. Mitchell, L. Roberts, op. cit., s. 49. 
Secesja w miejsce profili wprowadziła płaskie listwy, odrzuciła zasadę wzoru obiegającego i stosowała dowolne struktury. Przy tym można było umieścić na ramie wybujałe elementy przedstawienia plastycznego, pełne fantazji skojarzenia figuralne, kaligraficzne pola. W wielu przypadkach przybijano do poszerzonych podobrazi z drewna tylko cienkie listewki profilowe i malowano znajdujące się między nimi pola. Konstrukcje te były zbliżone do płaskich ram gotyckich retabulów. Zrozumiałe jest to, że obok tak zróżnicowanej formy obramienia przerabiano ramy stare. Dotyczyło to szczególnie tych z egzotycznymi, pełnymi wdzięku ozdobami dekoracji ludowej.

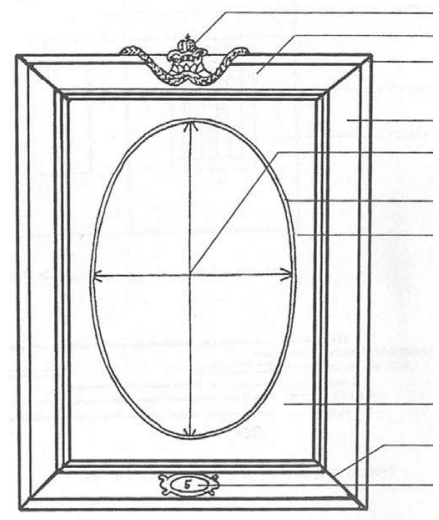

Rys. 1. Schematyczna budowa ramy, za: I. Grzeluk, Stownik terminologii mebli, Biblioteka Muzealnictwa i Ochrony Zabytków, Warszawa 1998, s. 225

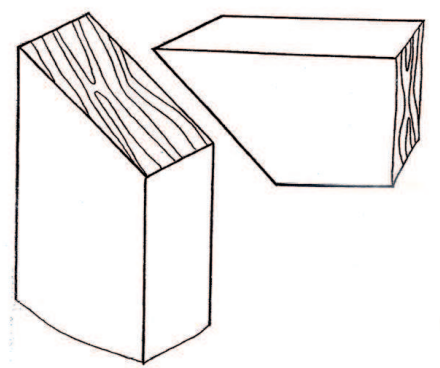

Rys. 3. Złącze stolarskie, uciosowe (rys. P. Tuliszewski)

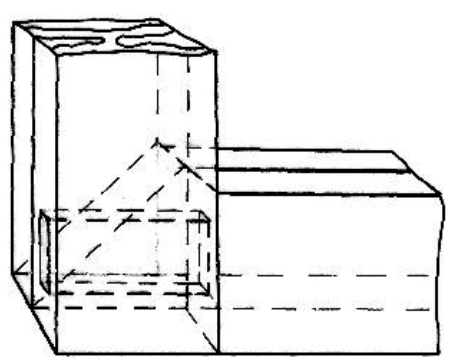

Rys. 2. Złącze stolarskie, czopowo-uciosowe (rys. P. Tuliszewski)

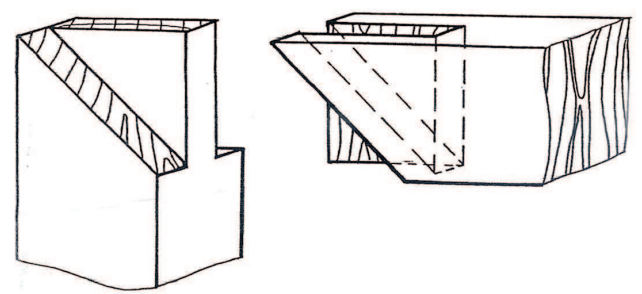

Rys. 4. Złącze stolarskie, uciosowo-zakładkowe (rys. P. Tuliszewski) 


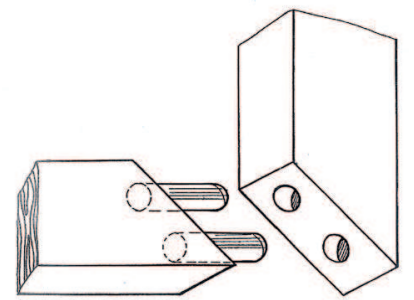

Rys. 5. Złącze stolarskie, uciosowe, kołkowe (rys. P. Tuliszewski)

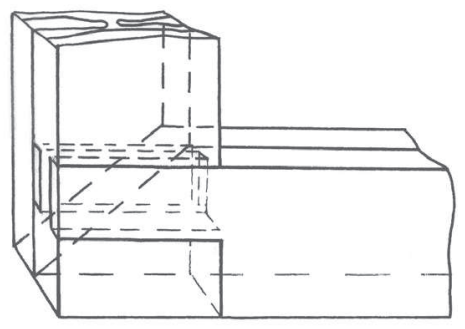

Rys. 7. Złącze stolarskie, czopowo-uciosowe, kołkowe (rys. U. Wantuch)

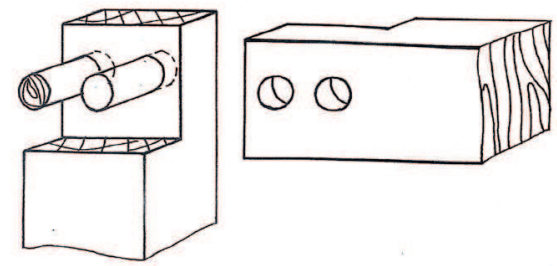

Rys. 9. Złącze stolarskie, zakładkowe, kołkowe (rys. P. Tuliszewski)

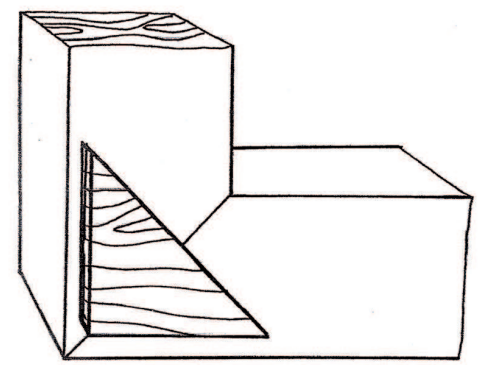

Rys. 6. Złącze stolarskie, uciosowe, wzmocnione trójkątem (rys. P. Tuliszewski)

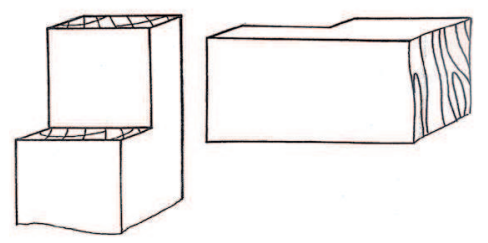

Rys. 8. Złącze stolarskie, zakładkowe, proste (rys. P. Tuliszewski)

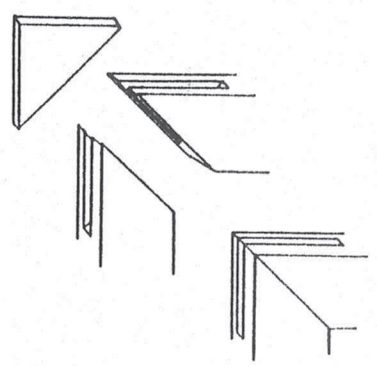

Rys. 10. Złącze stolarskie, na obce pióro (rys. U. Wantuch) 


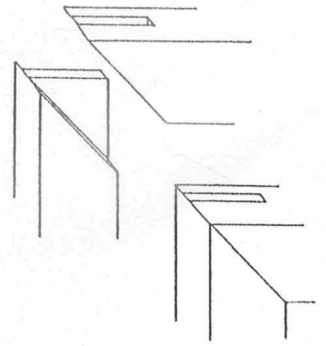

Rys. 11. Złącze stolarskie, na wpust (rys. U. Wantuch)
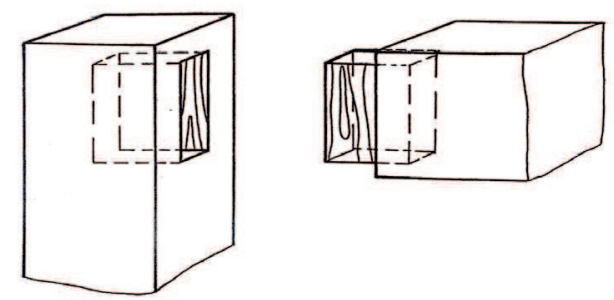

Rys. 12. Złącze stolarskie, czopowe, kryte (rys. P. Tuliszewski)

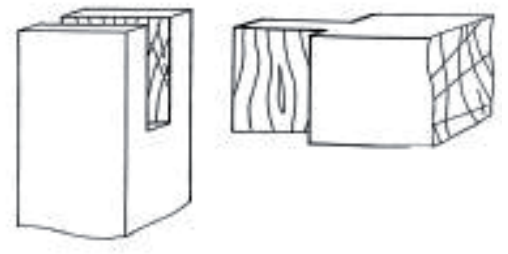

Rys. 13. Złącze stolarskie, czopowe, przelotowe (rys. P. Tuliszewski)

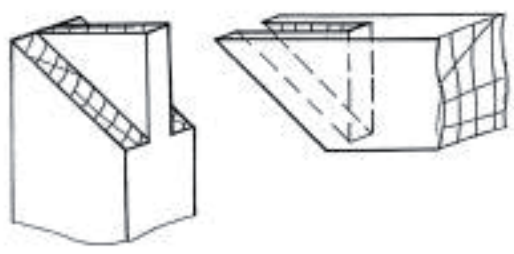

Rys. 14. Złącze stolarskie, czopowe, uciosowe, pojedyncze (rys. P. Tuliszewski)
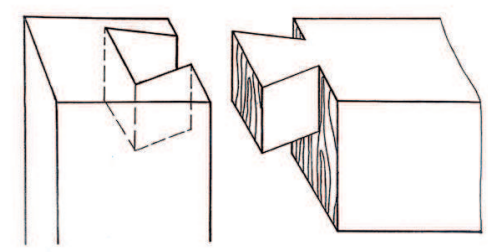

Rys. 15. Złącze stolarskie, płetwowe (rys. P. Tuliszewski)
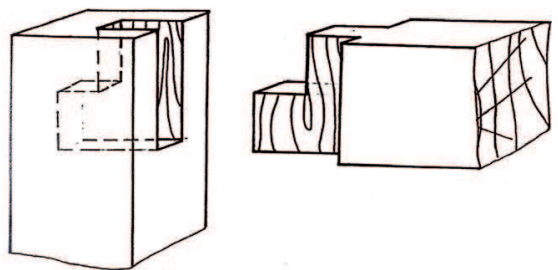

Rys. 16. Złącze stolarskie, czopowe, osadzone (rys. P. Tuliszewski) 


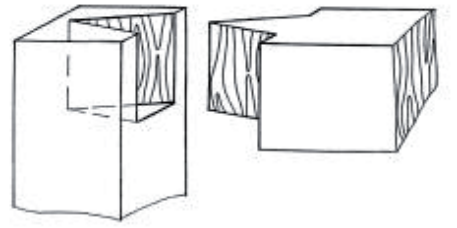

Rys. 17. Złącze stolarskie, czopowe, kryte, pojedyncze, ścięte (rys. P. Tuliszewski)

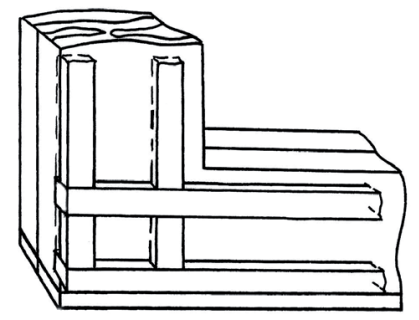

Rys. 19. Złącze stolarskie, XIX-wieczna konstrukcja złożona (rys. U. Wantuch)

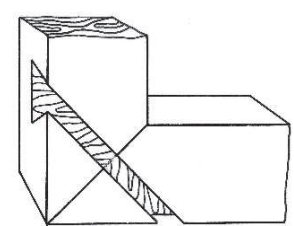

Rys. 18. Złącze stolarskie, uciosowe, wzmocnione kluczem (rys. P. Tuliszewski)
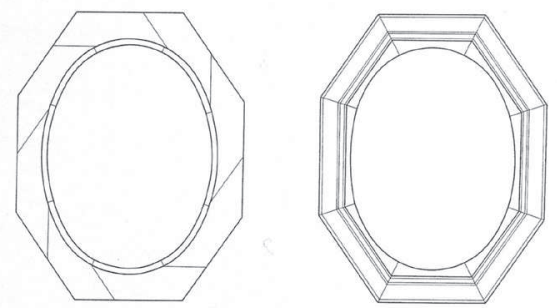

Rys. 20. Konstrukcja ram wielokątnych, wielokątna rama o świetle owalnym, za: P. J. J. Van Thiel, C. J. Kops De Bruyn, Framing in the Golden Age, Picture and Frame in $17^{\text {th }}$ Century Holland, Amsterdam 1995, s. 67

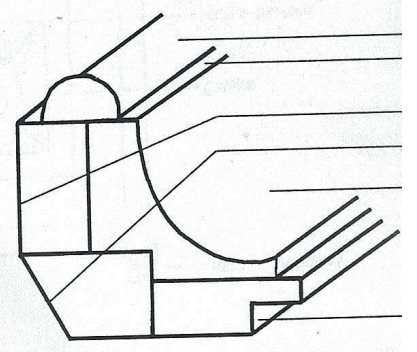

Rys. 21. Rama - przekrój poprzeczny, za: I. Grzeluk, op. cit., s. 303 


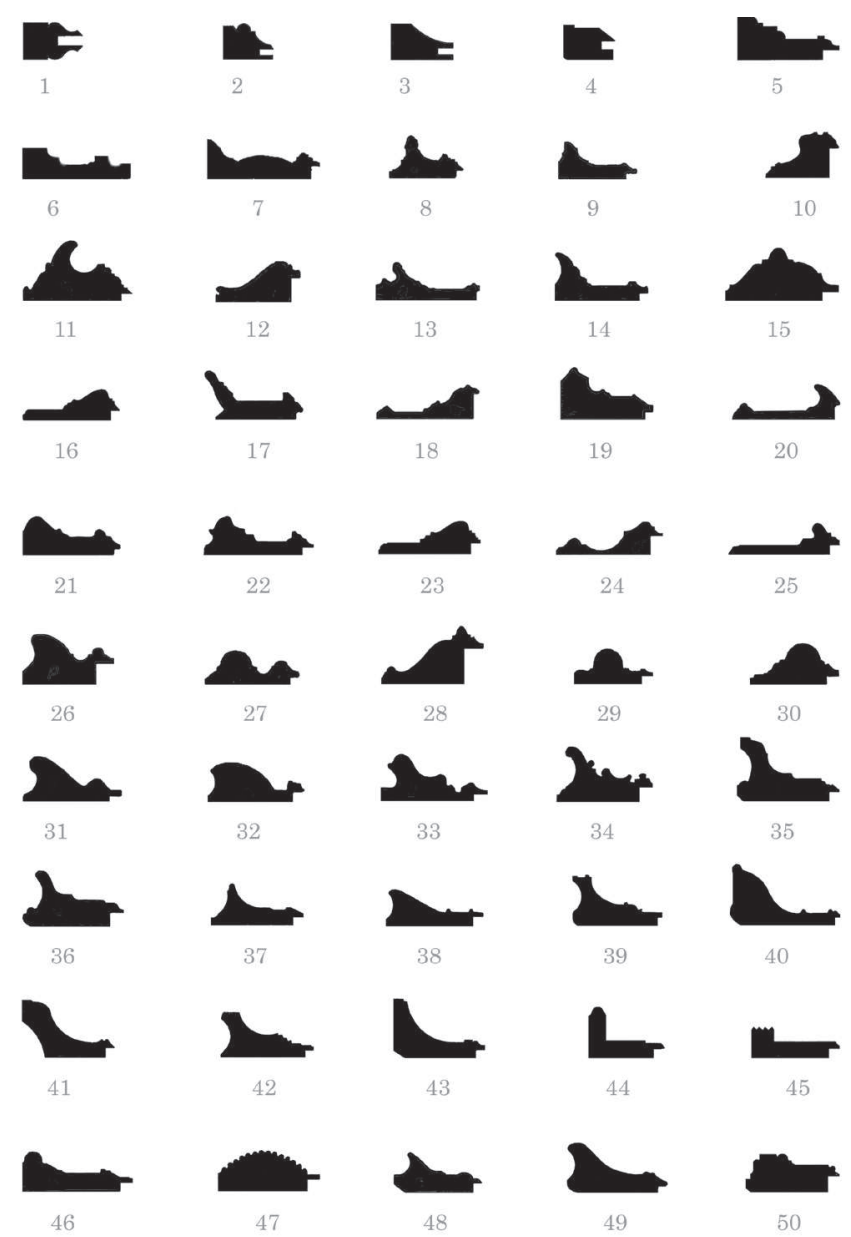

Rys. 22. Ewolucja kształtu profilu, za: P. Mitchell, L. Roberts, A bistory of European Picture Frames, London 1996, s. 20, 22, 25, 33, 38, 39, 43, 44, 49, 50, 51, 52, 57, 59, 67, 90, 93, 96, 122, 124, 136 (oprac. U. Wantuch):

1-5 - XIV w., 6 - pocz. XVI w., 7 - pocz. XIV w., 8 - pocz. XVI w., 9 - poł. XVI w., 10 poł. XVI w., 11 - 1 poł. XVI w., 12 - pocz. XVI w., 13 - 1 poł. XVI w., $14-1$ poł. XVI w., $15-2$ poł. XVI w., $16-1$ poł. XVII w., $17-1$ poł. XVII w., $18-1$ poł. XVII w., $19-$ poł. XVII w., $20-2$ poł. XVII w., 21 - XVI/XVII w., $22-1$ poł. XVII w., $23-1$ poł. XVII w., $24-1$ poł. XVII w., $25-2$ poł. XVII w., $26-1$ poł. XVII w., 27 - poł. XVII w., 28 - poł. XVII w., $29-2$ poł. XVII w., $30-2$ poł. XVII w., 31 - k. XVII w., $32-$ pocz. XVIII w., 33 - poł. XVIII w., 34 - poł. XVIII w., 35 - k. XVIII w., 36 - k. XVIII w., 37 - k. XVIII w., 38 - k. XVIII w., 39 - pocz. XIX w., 40 - pocz. XIX w., 41 - pocz. XIX w., $42-1$ pol. XIX w., 43 - lata 30. XIX w., 44 - lata 60. XIX w., 45 - lata 70. XIX w., $46-2$ poł. XIX w., 47 - lata 90. XIX w., 48 - lata 90. XIX w., 49 - lata 90. XIX w., 50 - k. XIX w. 

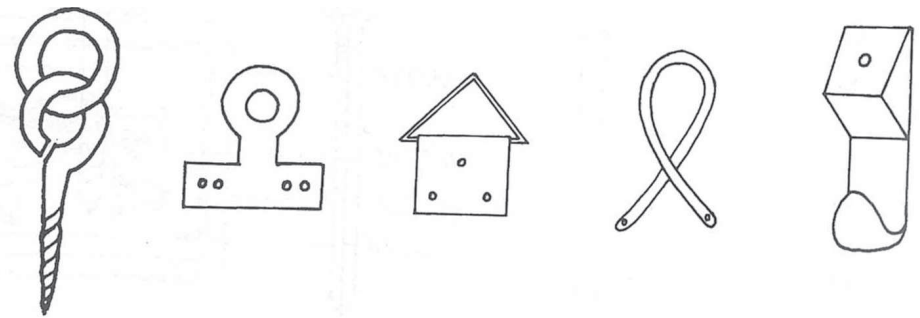

Rys. 23. Rodzaje zawieszek, za: I. Grzeluk, op. cit., s. 225
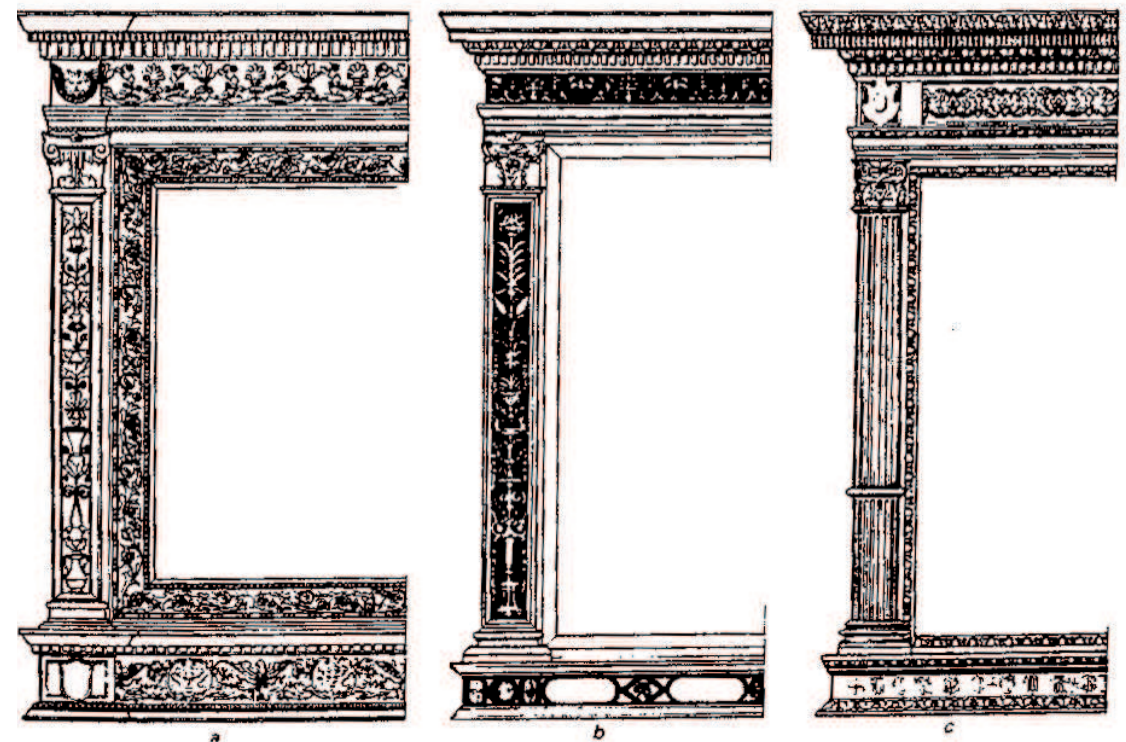

Rys. 24. Ramy włoskie renesansowe typu „tabernakulum”: a) wenecka rama z dekoracja pastiglia, 1512 r.; b) toskańska rama wykonana z drewna orzecha, częściowo złocona, ok. 1540 r.; c) północnowłoska rama, ok. 1490 r., za: P. Mitchell, L. Roberts, op. cit., s. 19 


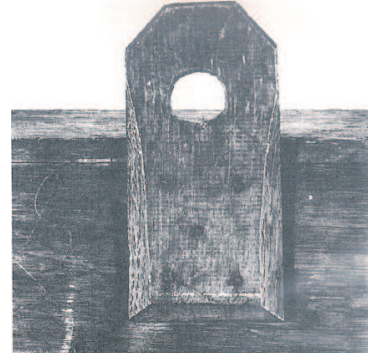

Il. 1. Drewniany haczyk, XVII w., rama holenderska, Rijksmuseum, za: P. J. J. Van Thiel, C. J. Kops De Bruyn, Framing in the Golden Age, Picture and Frame in $17^{\text {th }}$ Century Holland, Amsterdam 1995, s. 64

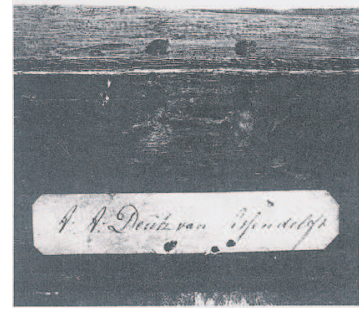

Il. 2. Ślad po sznurku służącym do zawieszania ramy, koniec XVI w., za: P. J. J. Van Thiel, C. J. Kops De Bruyn, op. cit., s. 103

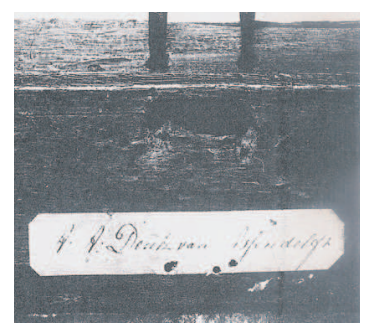

Il. 3. Zawieszka - sznurek, koniec XVI/początek XVII w., rama holenderska, Rijksmuseum, za: P. J. J. Van Thiel, C. J. Kops De Bruyn, op. cit., s. 64

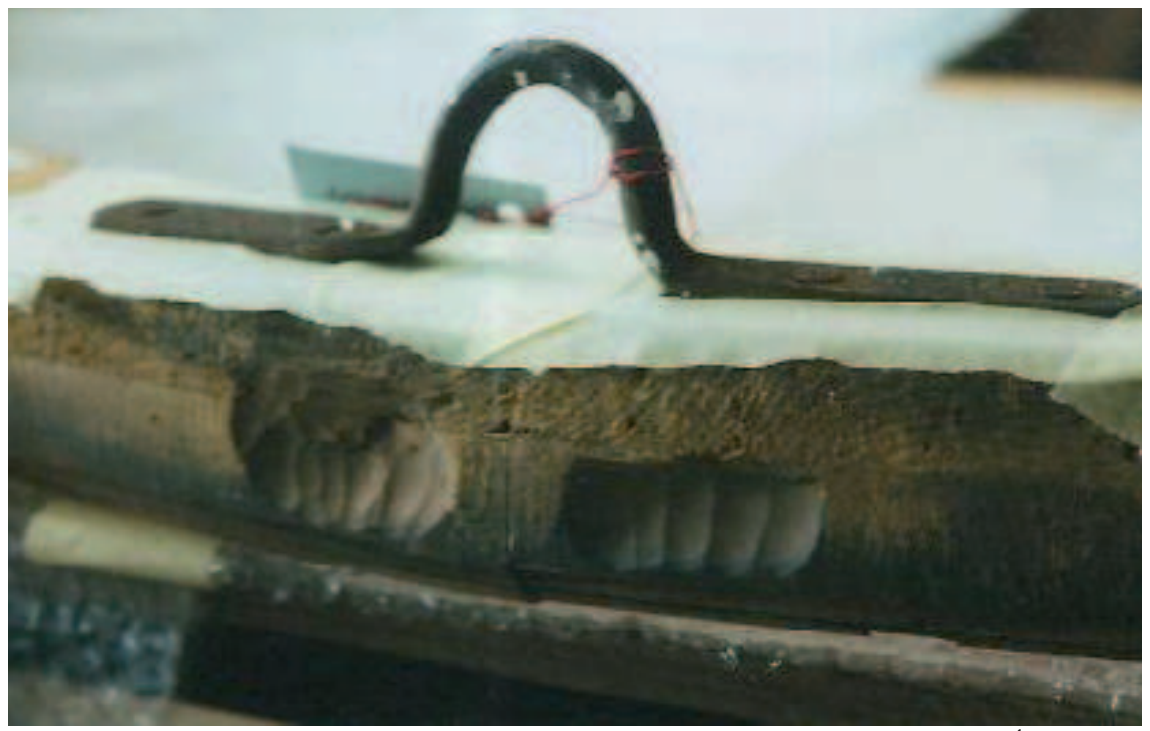

Il. 4. Metalowa zawieszka do obrazu dużego formatu, XIX w., rama do obrazu Święta Trójca, klasztor Panien Dominikanek, ok. 1850 r., Piotrków Trybunalski, nr inw. ZKMiRZP 1231 (fot. K. Wantuch-Jarkiewicz) 


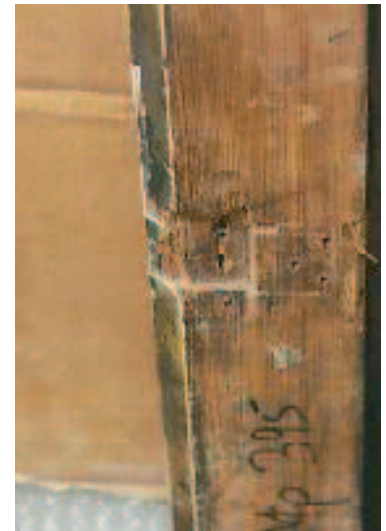

Il. 5. Ślad po zawieszce, XIX w., rama, wł. Muzeum Narodowe w Poznaniu, nr inw. ZKMiRZP 1127 (fot. K. Wantuch)

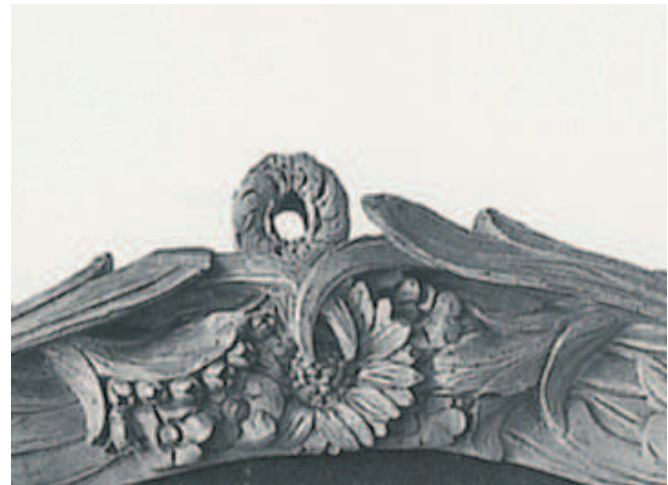

Il. 6. Północnoniderlandzka rama, ok. 1660 -1665 r., Rijksmuseum (zawieszka często była podobnie zdobiona jak sama rama), za: P. J. J. Van Thiel, C. J. Kops De Bruyn, op. cit., s. 34

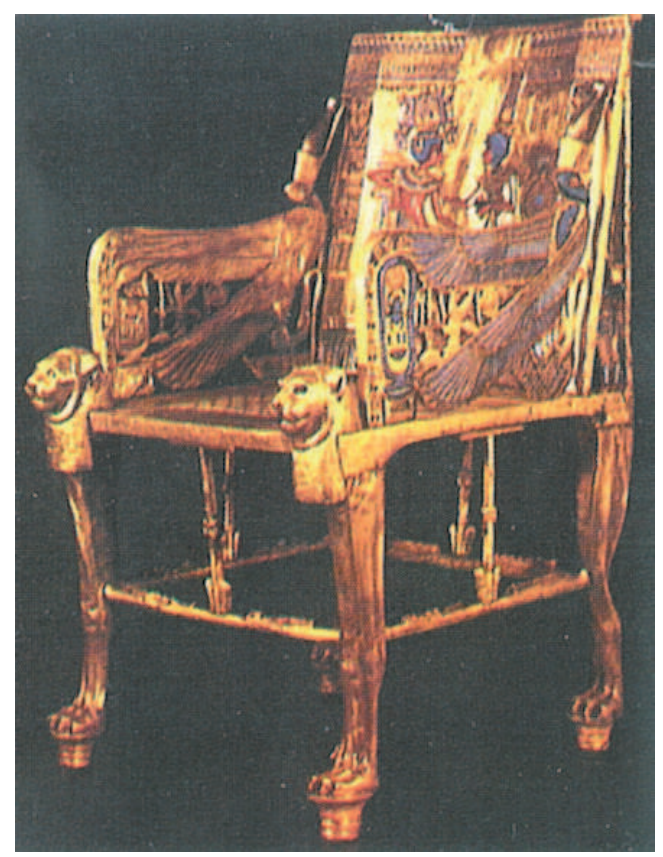

Il. 7. Krzesło pochodzace $\mathrm{z}$ grobowca Tutenchamona, Dynastia XVIII, za: R. Montenegro, Meble, Warszawa 2001, s. 8 


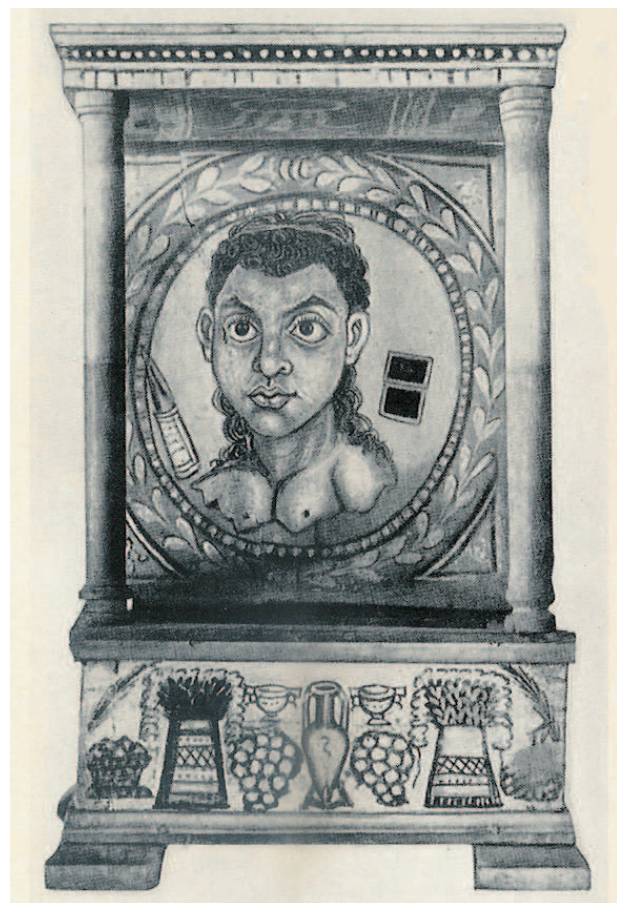

Il. 8. Rama w kształcie edykuły wokół portretu fajumskiego, połowa I w. n.e., za: E. Werner, Bilderrahmen von der Antike bis zur Romanik, Dresden 1979, il. 28

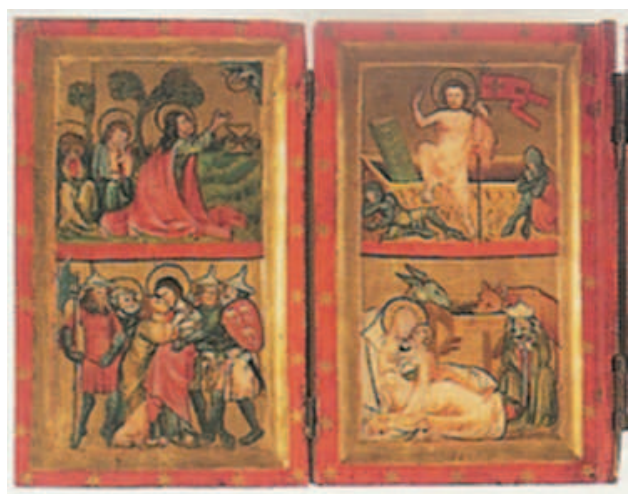

Il. 9. Kwadryptyk ze scenami z życia Marii, Śląsk, 1370 r., kościół Klarysek we Wrocławiu, za: $M u$ zeum Narodowe w Warsqawie. Przewodnik, Warszawa 1998, s. 98 


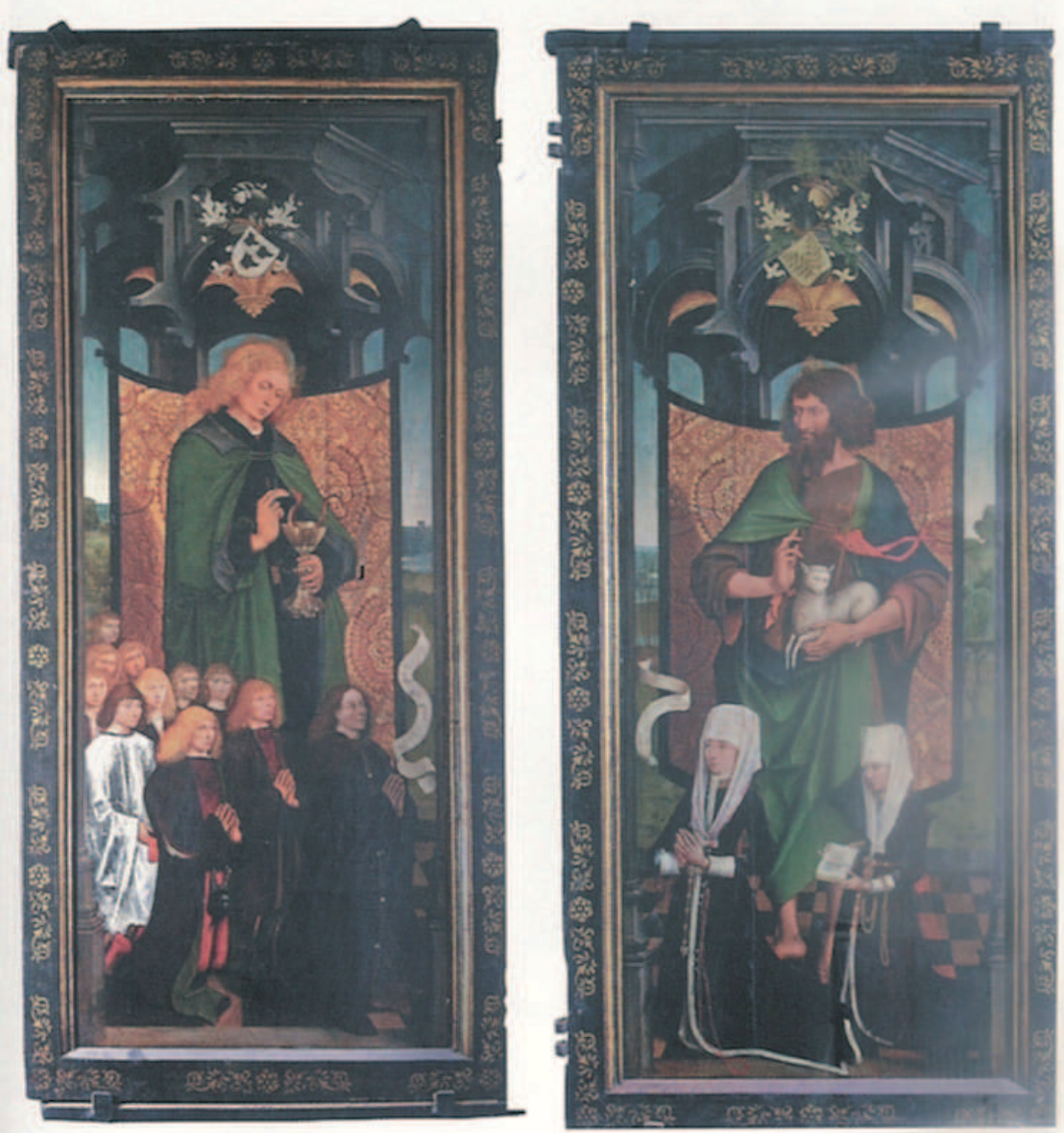

Il. 10-11. Retabulum Duśy Ottarz Ferberów, Gdańsk, 1480-1498, awersy skrzydeł ruchomych, za: J. Olszewska-Świetlik, Technologia i technika gdańskiego malarstwa tablicowego drugiej połowy XV w., Toruń 2005, il. 16 


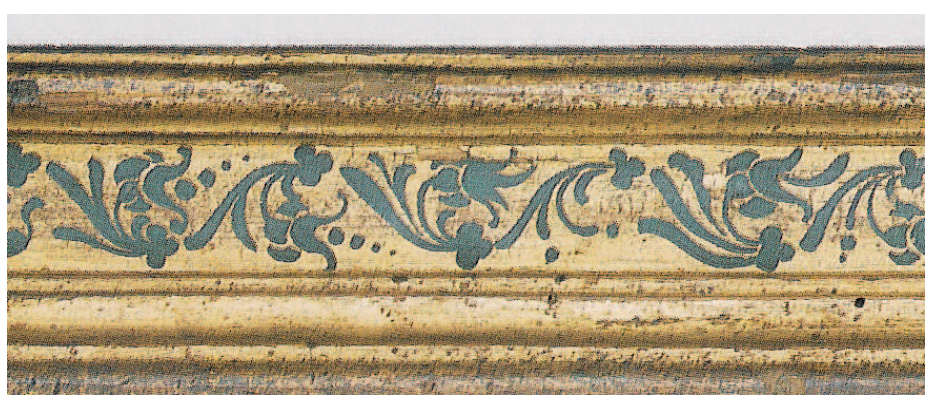

Il. 12. Technika złotego sgraffito, za: P. Mitchell, L. Roberts, Frameworks Form, Function \& Ornaments, London 1996, s. 41

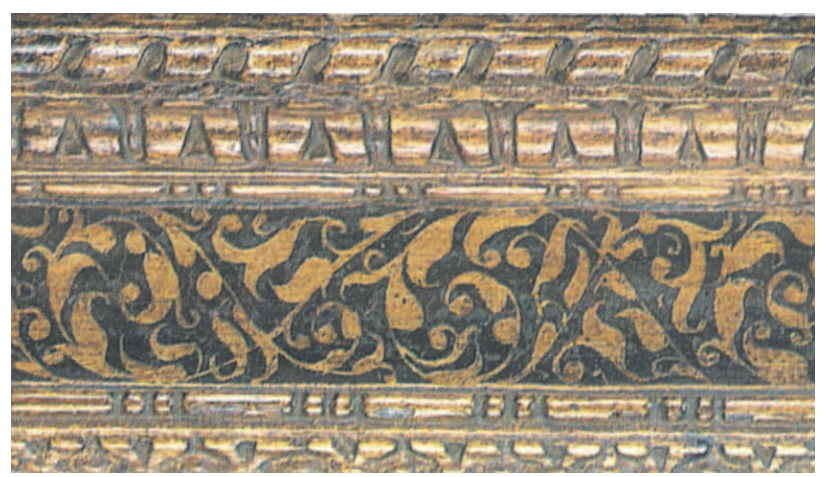

Il. 13. Technika malowania złotem, za: P. Mitchell, L. Roberts, Frameworks Form, s. 41

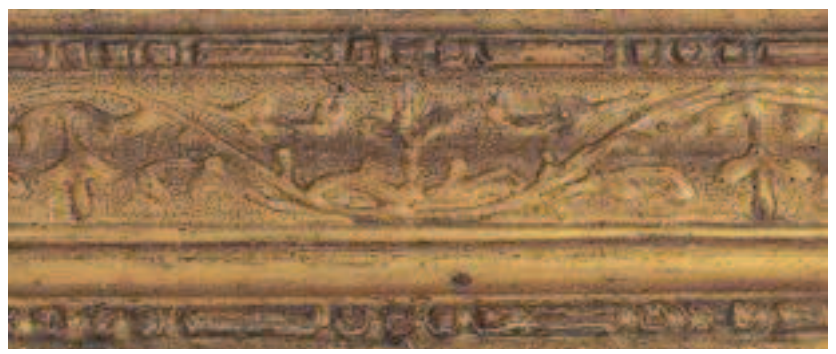

Il. 14. Technika aggetti, za: P. Mitchell, L. Roberts, Frameworks Form, s. 28 


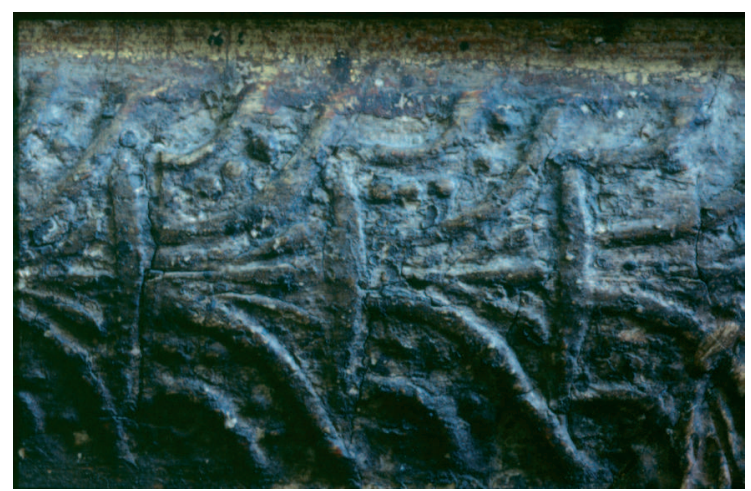

Il. 15. Technika pastiglia, rama do obrazu A. Tommasso Portret męzrsyzny, Rijksmuseum, Amsterdam, nr inw. A 3060

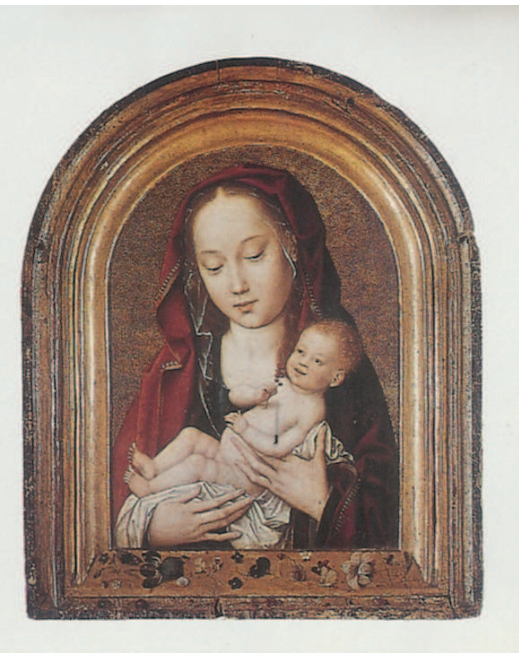

Il. 16. Rama zdobiona dekoracją malarską w technice trompe-o'eil, szkoła flamandzka, Madonna ₹ Drieciatkiem, XV w., Lisbona, Calouse Gulbenkian Museum, za: P. Mitchell, L. Roberts, Frameworks Form, il. 54, s. 89

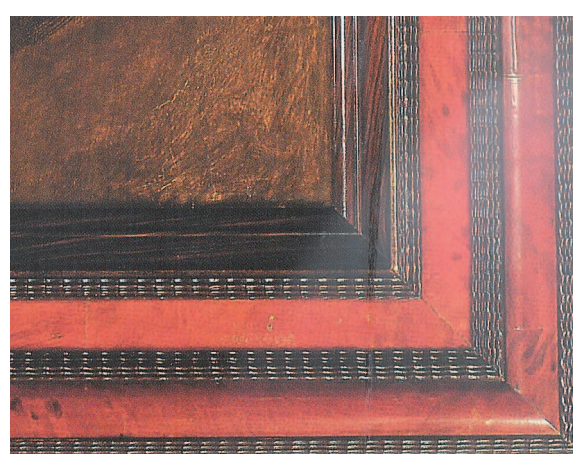

Il. 17. Florencka rama zdobiona szylkretem, druga połowa XVII w., za: P. Mitchell, L. Roberts, Frameworks Form, il. 68, s. 104 


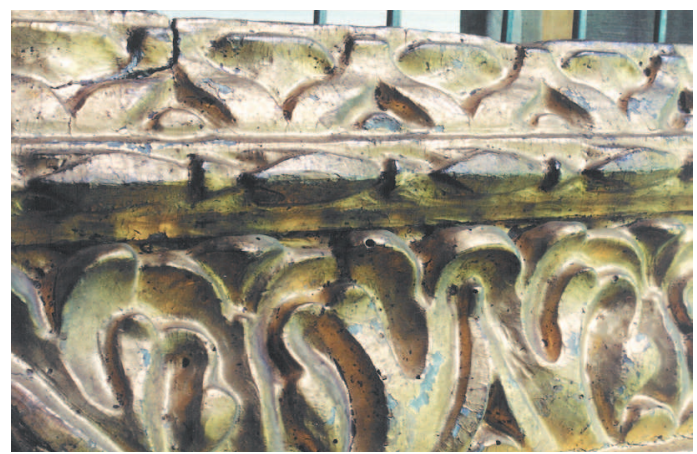

Il. 18. Wenecka rama z początku VII w., złocona w technice wodnej na poler, Rijksmuseum, Study Collection, nr inw. Rijksmuseum C. 1373 (fot. K. Wantuch-Jarkiewicz)

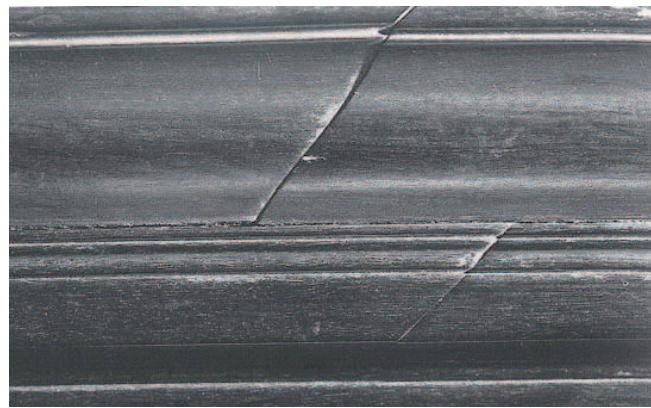

Il. 20. Rama holenderska, hebanowa. Zbliżenie połączenie forniru, za: P. J. J. Van Thiel, C. J. Kops De Bruyn, op. cit., s. 138

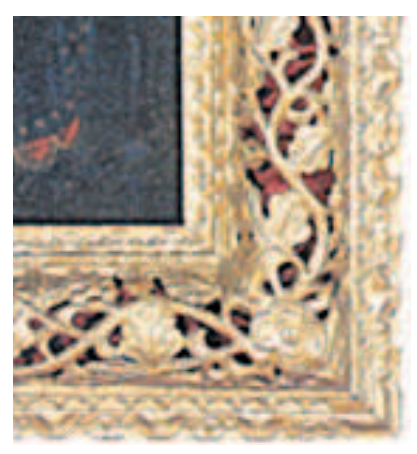

Il. 19. Barokowa rama typu flamandzkiego, Gdańsk, VII w., za: T. Mielniczuk, B. Grzegorzewski, Historia ramy do obrazu, Warszawa 1998, s. 20

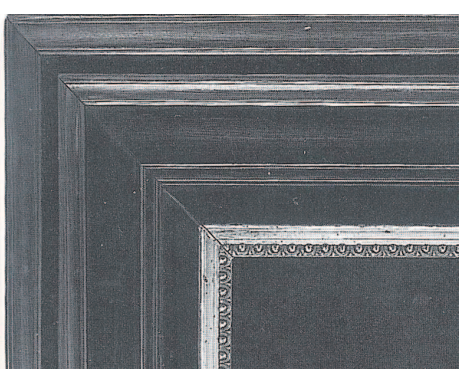

Il. 21. Czarna rama $z$ hebanowym fornirem i złoceniem przy wewnętrznej krawędzi ramy, za: P. J. J. Van Thiel, C. J. Kops De Bruyn, op. cit., s. 177 


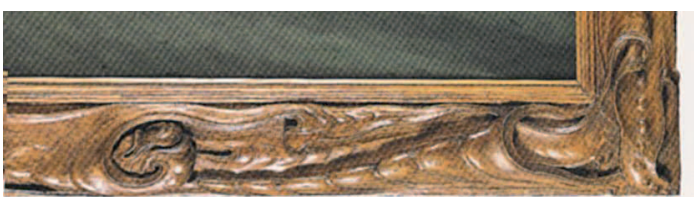

Il. 22. Rama typu „Lutma”, dębowa, za: P. J. J. Van Thiel,

C. J. Kops De Bruyn, op. cit., s. 103

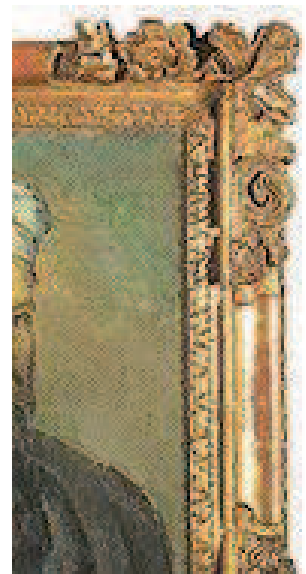

Il. 23. Rama w ,stylu Ludwika XIV". Pomiędzy ornamentami rzeźbionymi w zaprawie sa wycięte tzw. lustra, za: P. Mitchell, L. Roberts, Frameworks Form, s. 149

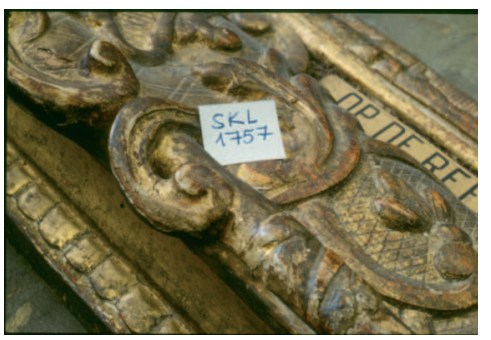

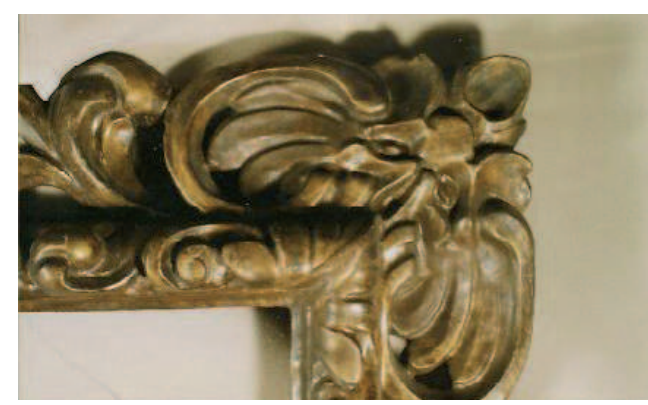

Il. 24. Rama hiszpańska/portugalska do obrazu Ecce Homo, XVII w., Muzeum Narodowe w Poznaniu (fot. W. Grzesik)

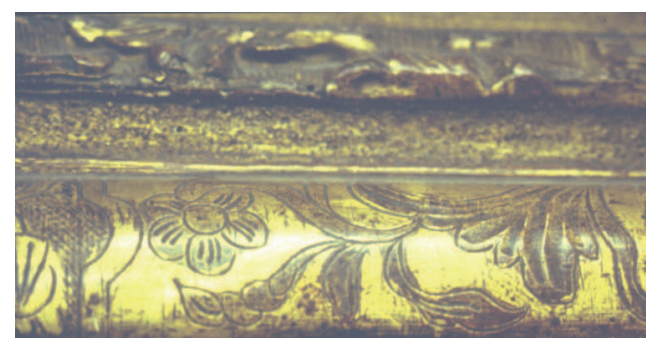

Il. 25. Grawerowana rama w ,stylu Ludwika XIV”, Rijksmuseum. Amsterdam, Study Collection, nr inw. Rijksmuseum A 3857 (fot. K. Wantuch-Jarkiewicz)

Il. 26. Rama w „stylu Ludwika XIV”, Rijksmuseum, Amsterdam, Study Collection, nr inw. Rijksmuseum SKL 1757 (fot. K. Wantuch-Jarkiewicz) 


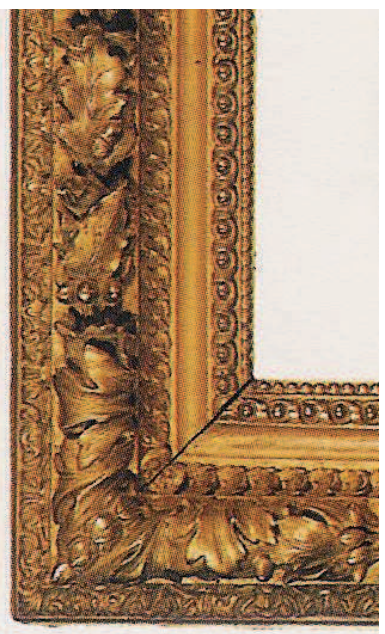

Il. 27. Rama w ,stylu Ludwika XIII", Collection Georges Bac, Le Cadre et le Bois Dore, Levallois 1991, s. 46

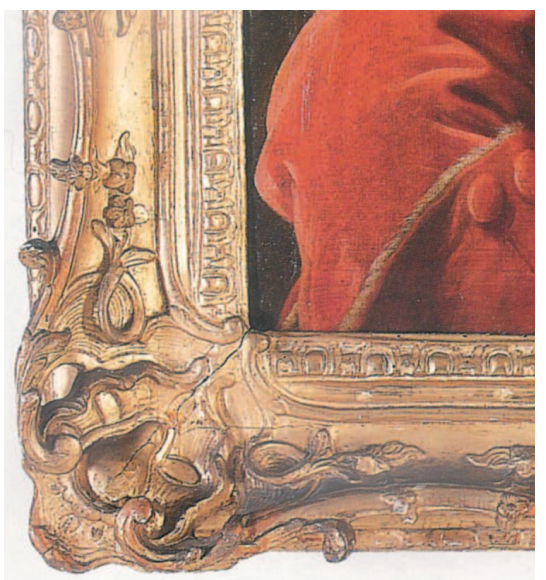

Il. 29. Rama w ,stylu Ludwika XV”, za: P. Mitchell, L. Roberts, Frameworks Form, s. 167

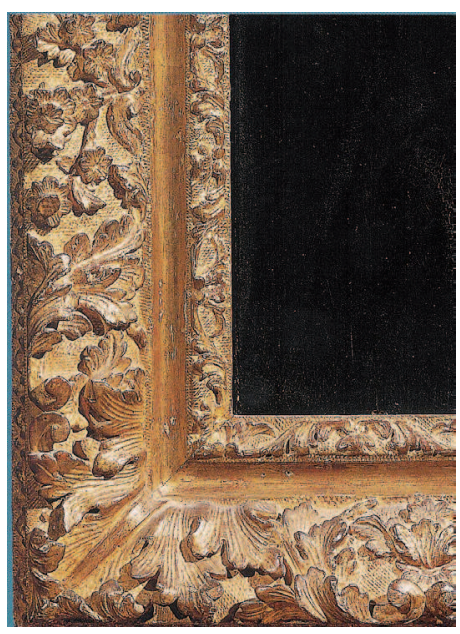

Il. 28. Rama w „stylu Ludwika XIV”, za: P. Mitchell, L. Roberts, Frameworks Form, s. 154

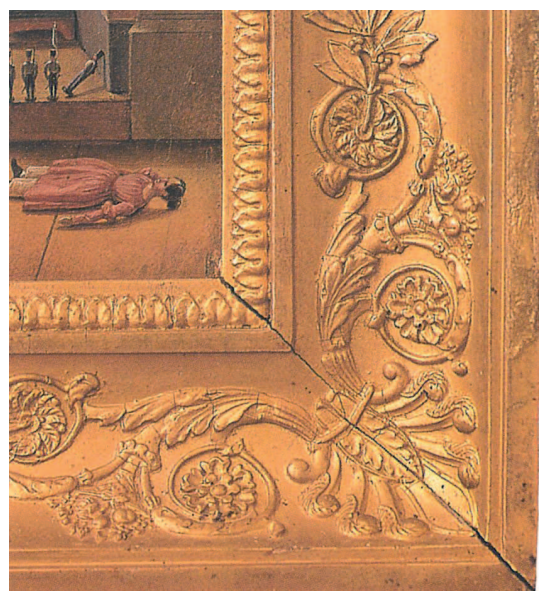

Il. 30. Rama w stylu empire, za: P. Mitchell,

L. Roberts, Frameworks Form, s. 335 


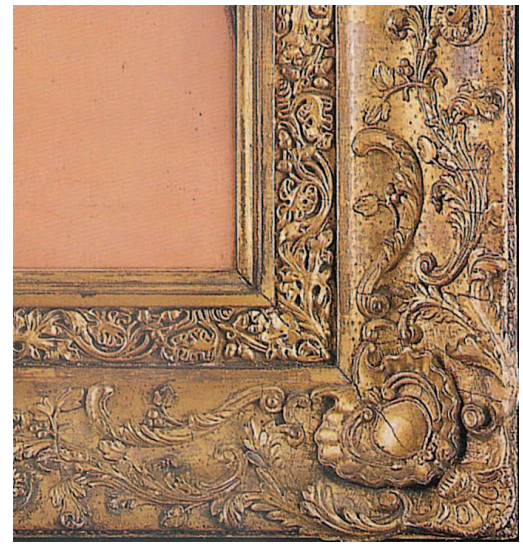

Il. 31. Rama neoklasycystyczna, za: J. Simon, The Art of the Picture Frame, Artists, Patrons and the Framing of Portraits in Britain, National Portrait Gallery, London 1996, s. 101

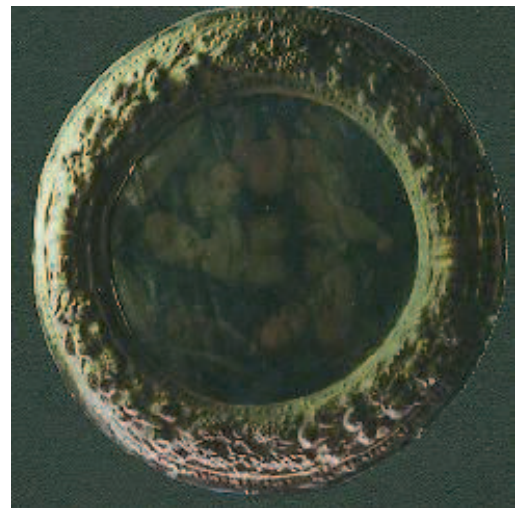

Il. 33. XIX-wieczna rama wykonana $\mathrm{z}$ papier mâché $\mathrm{w}$ typie renesansowego tonda, Rijksmuseum, nr inw. A 3378 (fot. K. Wantuch-Jarkiewicz)

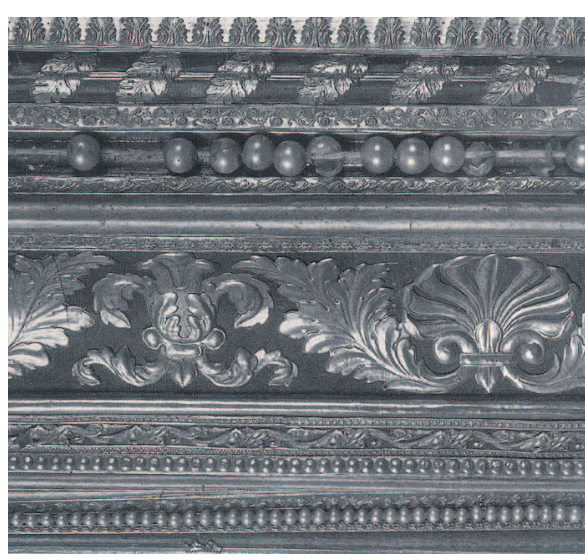

Il. 32. Fragment ramy wykonanej ze złoconego papier mâché z 1845 r., za: A. Hückel, Picture frames in the nineteenth century, [w:] A. Lins et al., Gilded Wood, Conservation and History, Madison 1991, s. 122

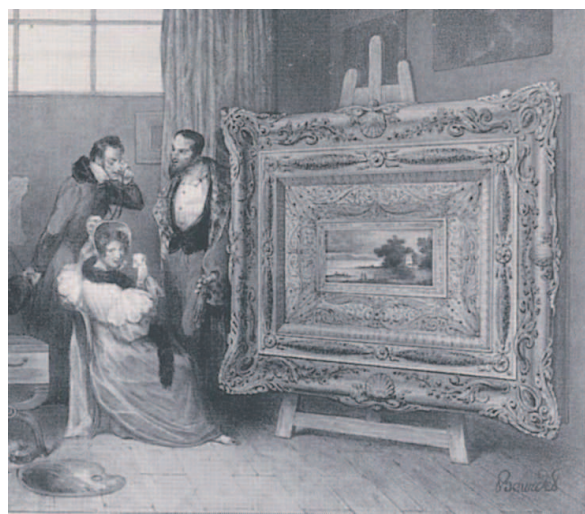

Il. 34. Karykatura ukazująca absurd szerokich złoconych ram XIX-wiecznych wystawianych na Salonach, za: J. Simon, op. cit., s. 19 


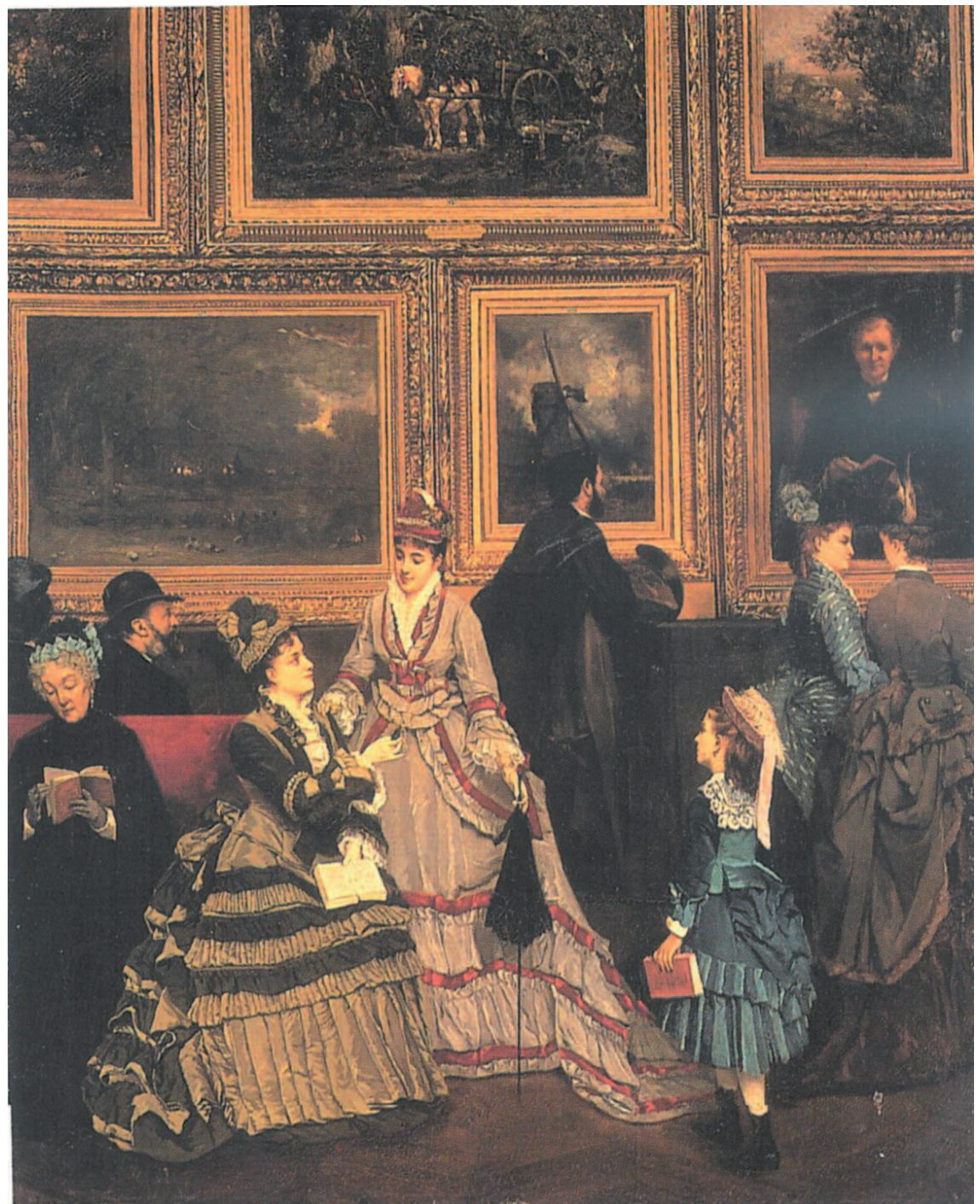

Il. 35. Rama typu „barbizon”, za: J. Bérard, Drień na Salonie 1874 r., 1874 r., za: P. Mitchell, L. Roberts, Frameworks Form, s. 349 


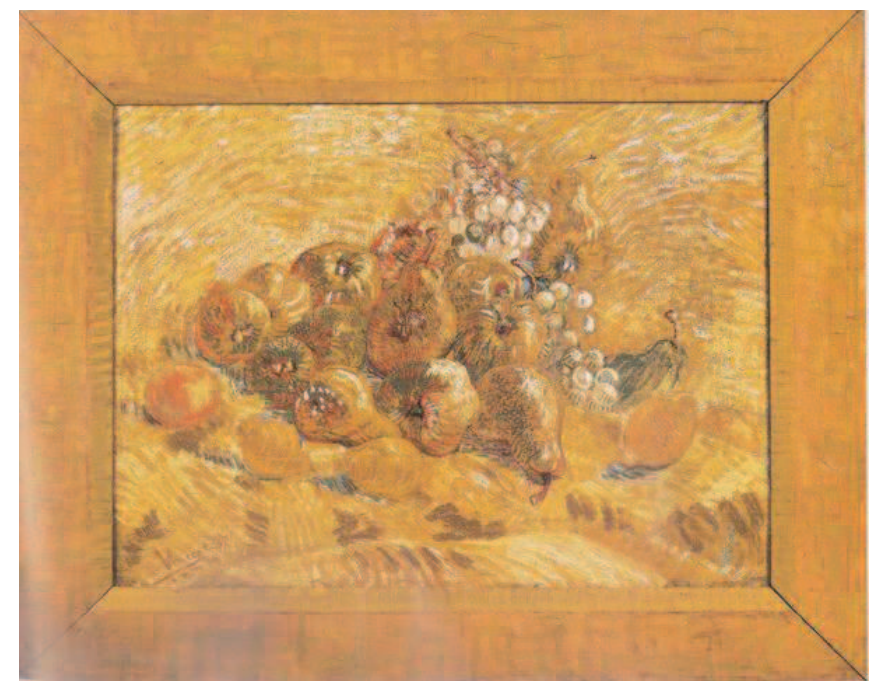

Il. 36. Vincent van Gogh, Martwa natura z owocami, 1887 r., Van Gogh Museum, Amsterdam, za: In Perfect Harmony, Picture + Frame, 1850-1920, ed. by E. Mendgen, Amsterdam 1995, s. 165

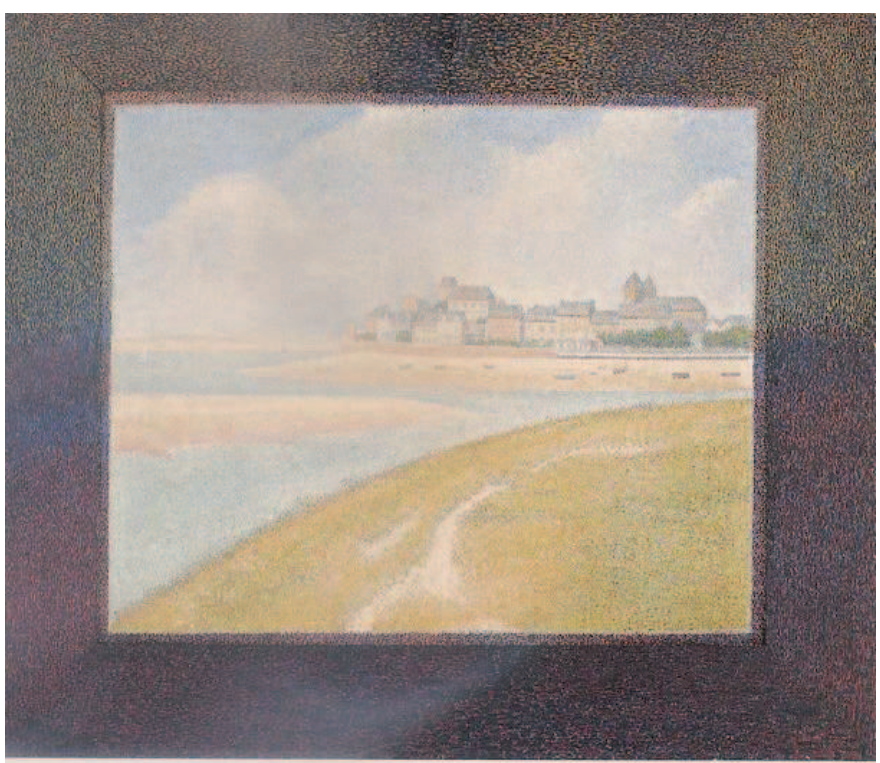

Il. 37. Georges Seurat, Le Crotoy, 1889 r., Musee d'Orsay, Paris, za: In Perfect Harmony, s. 158 


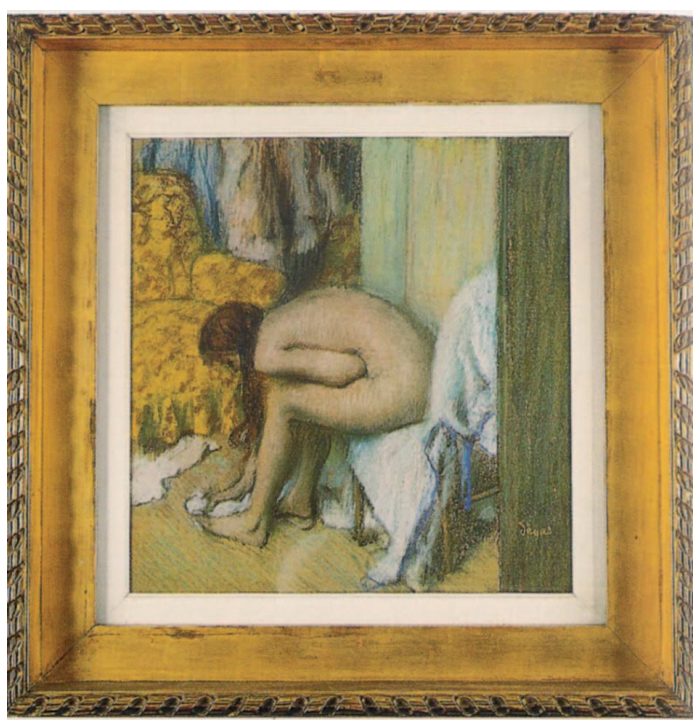

Il. 38. Edgar Degas, Akt, Myjaca lewa stope, 1886-1888, Musee d'Orsay, Paris, za: In Perfect Harmony, s. 138

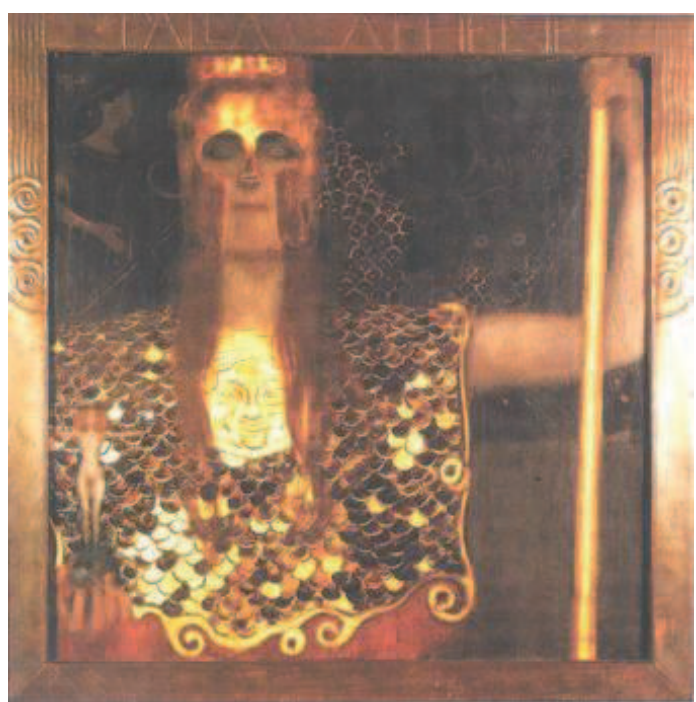

Il. 39. Gustav Klimt, Pallas Athena, 1898 r., Österreichische Galerie, Viena, za: In Perfect Harmony, s. 118 


\section{Summary}

\section{Gilded picture frames. Features of construction and decoration}

Picture frame is a combination of design and decoration. Each of these elements is composed of fine arts, the end result which is the harmony between the two functions of utilitarian and decorative. The techniques of manufacturing gilded frames and among these techniques to develop the ground, mordands and gilding as well as design features such as joints and joinery were presented. 